\title{
A hydrogeochemical approach to the characterization of low-enthalpy geothermal systems: the Scordia - Lentini graben (Sicily, Italy)
}

\author{
Gloria Maria Ristuccia*, Pietro Bonfanti, Salvatore Giammanco \\ (1) Istituto Nazionale di Geofisica e Vulcanologia, Sezione di Catania - Osservatorio Etneo, Italy
}

Article history: received July 30, 2020; accepted May 29; 2021

\begin{abstract}
We describe the geochemical characteristics of groundwater samples collected in 23 water wells located on the northern margin of the Hyblean plateau (East Sicily). This area, mostly made of highly permeable carbonate rocks, is rich in low temperature $\left(\mathrm{T}<50^{\circ} \mathrm{C}\right)$ hydrothermal groundwaters, distributed in an active sismogenetic zone, with several ENE-WSW-directed tectonic structures that drove magma to the surface during Upper Pliocene and Pleistocene. The chemical features suggest complex mixing between rainwater, $\mathrm{CO}_{2}$-rich groundwater, steam-heated groundwater and geothermal brines, as highlighted by Principal Component Analysis (PCA). Some parameters, however, indicate widespread pollution of the aquifers from human activities.

Stable isotopes analysis confirms the meteoric origin of groundwater and supports the origin of dissolved $\mathrm{CO}_{2}$ mostly from mantle degassing through deep tectonic faults. Geothermometric estimates, mostly based on quartz and Saturation Indexes geothermometers, suggest minimum reservoir temperature between 100 and $120^{\circ} \mathrm{C}$.
\end{abstract}

Keywords: Hydrothermal systems; Hyblean plateau; Water geochemistry; Stable isotopes; Principal Component Analysis; Geothermometry.

\section{Introduction}

In Italy, most of the energy used for industrial and domestic purposes is produced through the use of fossil fuels, which are mostly imported. Italy's energy dependence from foreign producers, combined with the commitments undertaken by the Italian government at international level about the reduction of green-house gas emissions into the atmosphere, makes it essential to promote scientific studies finalized to finding and exploiting alternative and renewable energy sources. In this context, geothermal energy plays a fundamental role, due to its broad availability on the Italian territory and its favorable cost-benefit balance [Lo Russo et al., 2009].

Sicily is probably one of the Italian regions with the highest geothermal potential, due to the many areas of active or recent volcanism and tectonism as well as of anomalous heat flow [Barberi et al., 1974; Bianchi et al., 1987; ENEL et al., 1988; Cataldi et al., 1995; Dall’Aglio et al., 1995; Schmincke et al., 1997; Della Vedova et al., 


\section{Gloria Maria Ristuccia et al.}

2001; Schiano et al., 2001; Trumpy et al., 2015; Minissale et al., 2019]. However, active volcanoes of Sicily, such as Mt. Etna, are not the best sites for the exploitation of geothermal resources, due to the presence of a large aquifer with cold groundwater that hampers the development of an efficient geothermal reservoir inside of the volcano [Giammanco et al., 1998a, 2018; Aiuppa et al., 2000a]. For this reason, our attention focused on other areas of Sicily, where volcanism was active in recent geological times and marked by deep regional faults where mantle gases are diffusely emitted in large amounts [Bonfanti et al., 1993; Dall'Aglio et al., 1995; De Gregorio et al., 2002; Grassa et al., 2002, 2006; Giammanco et al., 2007]. East Sicily represents the most interesting area for carrying out this type of research, due to both its peculiar volcanological and geological features [Lentini et al., 1996; Behncke, 2004; Bonforte et al., 2012] and the preliminary geochemical studies carried out in the past [Chiodini et al., 1996; Grassa, 2002; Minissale et al., 2019; Ristuccia et al., 2019].

The study area falls on the northern edge of the Hyblean plateau (north-eastern Sicily) (Figure 1) and it is rich in hydrothermal waters [Alaimo et al., 1978; Dongarra` and Hauser 1982; Capasso et al., 1992; Favara et al., 1998, 1999; Aiuppa et al., 2000a, 2000b; Capasso et al., 2001; Favara et al., 2001a, 2001b; Caracausi et al., 2004; Ristuccia et al., 2019]. The distribution of underground temperature indicates the presence of many positive thermal anomalies even at relatively shallow depth [Cataldi et al., 1995]. The local circulation of fluids at depth is strongly influenced by the main regional tectonic structures and during their ascent to the surface deep thermal fluids can mix with shallow waters.

In this paper we report geochemical data from 23 hypo-thermal waters $\left(\mathrm{T} « 85^{\circ} \mathrm{C}\right)$ collected from wells mainly drilled for irrigation purposes. The purpose of this work is to critically analyze, using hydrogeochemistry and liquid geothermometry, the chemical characteristics of local groundwaters, in order to understand the source of solutes and highlight all potential contributions from geothermal fluids [D'Amore and Panichi, 1985; Nicholson, 1993].

\section{Geological setting}

The Hyblean plateau (Figure 1), south eastern Sicily, is an undeformed foreland belonging to the African tectonic plate [Carbone et al., 1982; Grasso and Lentini, 1982; Carbone et al., 1987; Lentini et al., 1987; Ristuccia et al., 2013, 2019]. It is an autochthonous sedimentary cover of a thick carbonate succession mainly deposited as platform facies. The carbonate succession represents the roof of a Triassic dolomite formation located below an impermeable cover at depth of about $1000 \mathrm{~m}$ [Agip, 1978]. These Mesozoic to Cenozoic rocks contain substantial intercalations of volcanic deposits produced during several episodes since the Cretaceous until about 1.4 Ma [Bianchi et al., 1987; Schmincke, 1997; Behncke, 2004; Grasso et al., 2004]. To the east, the plateau is bounded by the NNW-SSE Hyblean-Maltese escarpment, one of the largest normal fault systems of the Mediterranean basin that separates the thick inland continental crust from the Ionian Mesozoic oceanic crust [Reuther et al., 1993; Adam et al., 2000]. This structural line is also responsible for the strong seismic activity of the region [Azzaro and Barbano, 2000; Monaco and Tortorici, 2000; Mattia et al., 2012]. To the north and to the west, the Hyblean plateau is bounded by the Gela-Catania Foredeep (Figure 1), an extensional belt forming a roughly NESW alignment down-bent under the front of the Appennine-Maghrebian chain by a NE-SW fault system [Beneo, 1960; Ogniben, 1969; Di Geronimo et al., 1978; Yellin-Dror et al., 1997; Lickorish et al., 1999]. The latter was generated by continental collision [Barberi et al., 1973; Boccaletti and Manetti, 1978; Patacca et al., 1990; Doglioni et al., 1999] between the northern edge of the African Plate and the Calabrian Arc. Two main extensional NE-SWoriented basins can be recognized along the Gela-Catania Foredeep: the Scordia-Lentini Graben, to the north, and the Marina di Ragusa Graben to the south [Grasso and Reuther, 1988; Grasso et al., 2000]. Both tectonic depressions, filled by Quaternary sedimentary deposits, are linked by a roughly N-S oriented fault system named Scicli-Ragusa fault system [Ghisetti and Vezzani, 1980; Grasso and Reuther, 1988). Recent studies [Bousquet and Lanzafame, 2004; Catalano et al., 2006, 2008, 2010; Neri et al., 2018; Henriquet et al., 2019] have demonstrated that since about $0.85 \mathrm{Ma}$, the normal faults controlling the Scordia-Lentini and the Marina di Ragusa extensional basins as well as the fault segments of the Scicli-Ragusa fault system, have been partially reactivated by reverse and left-lateral motions, respectively.

Upper Pliocene and Pleistocene volcanism developed in a shallow marine and locally subaerial environment [Schmincke et al., 1997]. Volcanic activity occurred in three main eruptive cycles and areas, differing in volume, 
chemical composition and eruptive mechanism. Most of the products, however, show a composition ranging from alkali basaltic to tholeiitic [Schmincke et al., 1997; Pedley et al., 2001]. Deposition of carbonate sediments occurred during the intervals between of volcanic activity, likely due to a transgressive event which is observed along the marginal areas of the Hyblean plateau.

The structural analysis pointed out the occurrence of three tectonic deformation stages characterized by ductile and brittle structures. During the Upper Pliocene-Lower Pleistocene an earlier extensional deformation occurred along the WSW-ENE fault system, induced by a N-S oriented extensional axis. This stage was followed by a compressive deformation event represented by E-W trending brittle and ductile structures affecting Lower Pleistocene carbonate sediments.

Structural analysis carried out along these structures pointed out a stress field characterized by a N-S oriented compressive axis, which also produced the compressive tectonic structures located south of Mt. Etna [Lanzafame et al., 1997; Monaco et al., 2002; Catalano et al., 2004]. This compressive stage was probably induced by frontal thrusting along the northern margin of Hyblean plateau.

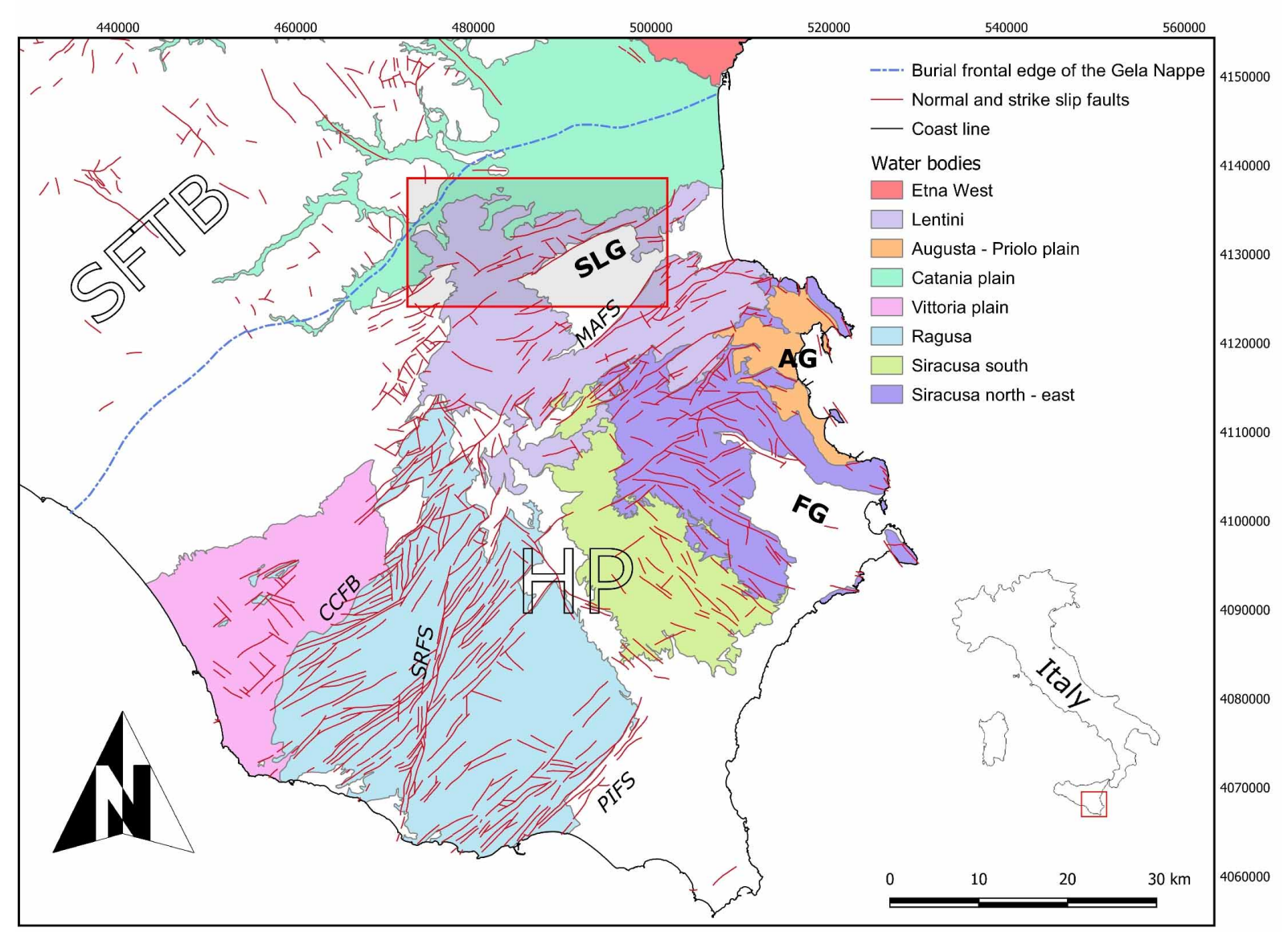

Figure 1. Schematic structural and hydrogeological map of SE Sicily, showing the main water bodies. The red square delimits the study area of Figure 2. Structural data from Carbone et al. (1987). Main geologic features: SFTB = Sicilian Fold and Thrust Belt; HP = Hyblean Plateau. Main tectonic features: SLG = Scordia-Lentini Graben, AG = Augusta Graben, and FG = Floridia-Graben. Main fault zones: CCFB = Comiso-Chiaramonte Fault Belt; MAFS = Monterosso-Agnone Fault System; SRFS = Scicli-Ragusa Fault System; PIFS = Pozzallo-Ispica Fault System. Coordinates are in UTM WGS84. 


\section{Gloria Maria Ristuccia et al.}

\section{Hydrological setting}

Several major hydrogeological structures were recognized in the Hyblean plateau [Aureli et al., 1989, 1997; Dall'Aglio et al., 1995; Grasso et al., 2000]:

i) Oligocene-Miocene carbonate successions (named Carbonate Aquifer), located in the central part of the area across its whole extension, cover an area of about $2300 \mathrm{~km}^{2}$. The total thickness of the aquifer down to the impermeable bed consisting of marls and clays (Lower Cretaceous) is estimated at about $1000 \mathrm{~m}$.

ii) Pleistocene calcarenites (named Calcarenitic Aquifer) host the main aquifer in the western part of the study area, whose thickness is variable due to progressive deepening of the impermeable beds. Permeability and transmissivity values of this aquifer are higher than $10^{-5} \mathrm{~m} / \mathrm{s}$ and $10^{-3} \mathrm{~m}^{2} / \mathrm{s}$, respectively, with variations that depend on both the degree of rock fracturing and karst dissolution processes.

iii) Upper Miocene to Quaternary biocalcarenites, alluvial and evaporitic deposits either occupy only marginal areas or outcrop along the main river incisions. Therefore, they constitute very small aquifers (named Marginal Aquifer) often affected by marine intrusions near the coast. Alluvial deposits, especially near the Lentini lake (Figure 2), consist of medium-to-fine sand and silt and have a permeability between $10^{-3}$ and $10^{-5} \mathrm{~m} / \mathrm{s}$.

iv) Volcanic deposits (named Volcanic Aquifer) extend over a surface of more than $1000 \mathrm{~km}^{2}$ in the northern portion of the plateau. Volcanites are widely distributed with considerable extension mostly in the areas located south of Palagonia (Figure 2) and to the east until the Lentini lake. Their thickness is highly variable (up to $500 \mathrm{~m}$ ), and they are in hydraulic continuity with the Pleistocene calcarenites. The hydrodynamic parameters of this aquifer, such as permeability and transmissivity values, are of $10^{-5} \mathrm{~m} / \mathrm{s}$ and $10^{-3} \mathrm{~m}^{2} / \mathrm{s}$, respectively.

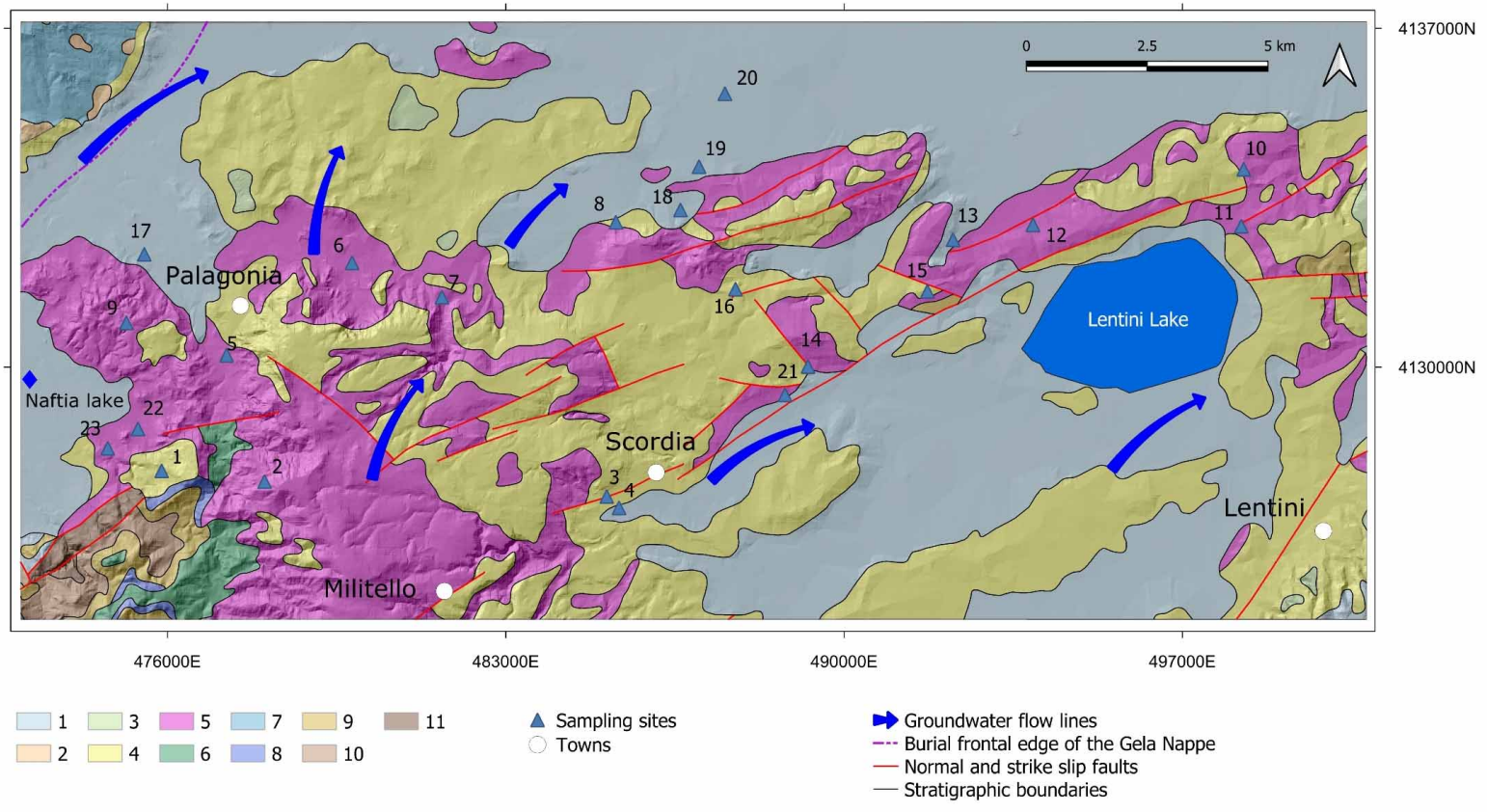

Figure 2. Map of the study area with location of sampling points, geological features and hydrogeological structures. Geological data from Carbone et al. (1987). 1: Undifferentiated continental, marine and terrace deposits; 2: Pre-evaporitic and evaporitic deposits; 3: Sands and clays of marine environment grading up to transitional and continental deposits; 4: Gela-Catania Foredeep and Hyblean Foreland clastic deposits; 5: Basaltic lava flows with minor pyroclastics (tholeiithic and alkaline affinities); 6: Trubi Formation (foraminifera-bearing marly limestones); 7: Grey-blue marly clays; 8: Evaporites with volcanic intercalations; 9: Carlentini formation (volcanics, marls and subordinated reef-limestones) and M. Carrubba formation (shallow water or fresh-water limestones); 10: Tellaro formation (marls and marly limestones with intercalations of mafic volcanites); 11: Ragusa formation (calcarenites and marls). 


\section{Geothermal systems in east Sicily}

\section{Methods}

\subsection{Study area}

Twenty-three groundwater samples from different sites located in the margin area of Palagonia (Figure 2) were collected and analysed in July 2002. Samples were mostly taken from the hydrogeological structures represented by the Carbonate and Volcanic aquifers, and the alluvial deposits close to the Lentini lake (Figure 2).

All samples are hypo-thermal waters with max temperature of $40.1^{\circ} \mathrm{C}$ (Table. 1) [Grassa et al., 2006; Ristuccia et al., 2019]. Thermalism seems to be caused by the uprise of deep fluids, partly produced from mantle degassing [Caracausi et al., 2003a, 2003b; Minissale et al., 2019; Ristuccia et al., 2019], along major tectonic structures. Actually, the study area is also characterized by the presence of a site (Naftìa lake - blue diamond in Figure 2) with very strong degassing of $\mathrm{CO}_{2}$ and other trace gases, whose origin is clearly mantle [De Gregorio et al., 2002; Grassa, 2002; Caracausi et al., 2003a, 2003b]. Furthermore, there seems to be a close correlation between the temporal variations of the gas concentrations at this site and those manifestations around Mt. Etna, thus suggesting a common magmatic source [Caracausi et al., 2003a, 2003b]. The connection with Mt. Etna plumbing system seems also supported by structural data, as both Naftìa lake and the main gas manifestations around the volcano are located on the NE-SW regional fault trend, which includes both the Gela Nappe and the Scordia-Lentini Graben itself (Figure 1), that is thought to be the prolongation south-westward of the Messina-Capo Vaticano lithospheric fault [Ogniben, 1969; Lo Giudice et al., 1982; Bousquet et al., 1988; De Gregorio et al., 2002].

\subsection{Sampling and analytical procedures}

Our samples were taken from pumped production wells, with depth of the cased portion that only in seven cases was known (ranging between 170 and $520 \mathrm{~m}$ below the surface; Table 1). In the other cases it was likely deeper than $50 \mathrm{~m}$ and probably close to $200 \mathrm{~m}$ as this seems to be the average depth for the wells in the study area. Before sampling and in-situ measurements, water from the pumps was allowed to run for several minutes. Samples were collected and stored in polyethylene bottles. Water and air temperature, $\mathrm{pH}$ and electrical conductivity (EC) were measured in the field with portable instruments. An Orion ${ }^{\mathrm{TM}}$ (Model 105) conductivity meter was used for the EC determination, allowing temperature compensated EC measurements (referred to $20^{\circ} \mathrm{C}$ ).

Both $\mathrm{pH}$ and Eh measurements were performed by using an Orion ${ }^{\mathrm{TM}}$ potentiometer (Model $205 \mathrm{~A}$ ), equipped, in the case of $\mathrm{pH}$, with an Orion ${ }^{\mathrm{TM}}$ Ross combination $\mathrm{pH}$ electrode (Model 8102) previously calibrated using $\mathrm{BDH} \mathrm{pH} 7$ and $\mathrm{pH} 4$ concentrated buffer solutions. $\mathrm{HCO}_{3}$ content was determined in the laboratory within $24 \mathrm{~h}$ from sampling by volumetric titration with $\mathrm{HCl} 0.1 \mathrm{~N}$ and methyl-orange as indicator.

At sampling, water samples were filtered with cellulose filters $(0.45 \mu \mathrm{m})$ and the major and minor constituents determined by Dionex 2000i ion chromatograph (reproducibility within 2.2\%). A Dionex CS-12 column was used for the cations ( $\mathrm{Li}, \mathrm{Na}, \mathrm{K}, \mathrm{Mg}, \mathrm{Ca}$ ), whereas a Dionex AS4A-SC column was used for the anions ( $\mathrm{F}, \mathrm{Cl}, \mathrm{NO}_{3}, \mathrm{SO}_{4}$ ) [Sortino et al., 1991]. Silica contents were determined by colorimetric techniques, without diluting or acidifying the samples upon collection, using a spectrophotometer Shimadzu UV 1601 and the ammonium molybdate method.

For the determination of trace metals, the sample was filtered at the time of sampling, with filters with porosity $0.45 \mu \mathrm{m}$ and maintained at a $\mathrm{pH}$ lower than 2 by adding $200 \mu \mathrm{L}$ of ultrapur $\mathrm{HNO}_{3}$. Trace element abundance analyses were performed using a Perkin Elmer ELAN-DRC Quadrupolar Plasma Source Mass Spectrometer (ICP-MS). The limit of determination for the elements considered varies from 0.01 to $0.1 \mu \mathrm{g} / \mathrm{L}$. Ion balance errors (in meq/L) were calculated for each sample based on total dissolved major species [Hem, 1985]. Eleven samples out of twenty-three showed errors within the $\pm 5 \%$ range, which indicates a good quality of these analyses [Appelo and Postma, 1993)]. The other samples showed ion balance errors in the range between $\pm 5 \%$ and $\pm 10 \%$, which, assuming correct analytical procedures, is still considered acceptable [Hem, 1985]. Actually, waters having dissolved-solids concentrations much greater than $1000 \mathrm{mg} / \mathrm{L}$, as in our case, tend to have large concentrations of a few constituents and the test of anion-cation balance does not adequately evaluate the accuracy of the values of the lesser constituents [Hem, 1985]. 
Gloria Maria Ristuccia et al.

\begin{tabular}{|c|c|c|c|c|c|c|c|c|c|}
\hline \multirow{2}{*}{ Sample Id } & \multirow{2}{*}{ Site } & \multicolumn{2}{|c|}{ Coordinates } & \multirow{2}{*}{$\begin{array}{c}\text { Depth } \\
\text { m }\end{array}$} & \multirow{2}{*}{$\begin{array}{c}\text { T(Wa) } \\
{ }^{\circ} \mathbf{C}\end{array}$} & \multirow[t]{2}{*}{ pH } & \multirow{2}{*}{$\begin{array}{l}\text { Eh } \\
\mathrm{mV}\end{array}$} & \multirow{2}{*}{$\begin{array}{l}\text { TDS } \\
\mathrm{mg} / \mathrm{L}\end{array}$} & \multirow{2}{*}{$\begin{array}{c}\mathrm{EC} \\
\mu \mathrm{S} / \mathrm{cm}\end{array}$} \\
\hline & & Easting & Northing & & & & & & \\
\hline 1 & Sessa & 475875 & 4127853 & 250 & 26.6 & 8.31 & 190 & 2736 & 2370 \\
\hline 2 & Scala Bianca & 478005 & 4127633 & n.m. & 18.6 & 7.71 & 212 & 357 & 385 \\
\hline 3 & Pignatazza & 485086 & 4127323 & 380 & 26.0 & 9.25 & 175 & 403 & 408 \\
\hline 4 & Via Simeto & 485341 & 4127089 & 170 & 19.8 & 7.50 & 194.1 & 711 & 623 \\
\hline 5 & Motta & 477221 & 4130243 & 520 & 40.1 & 6.72 & -362 & 1662 & 1424 \\
\hline 6 & Vita & 479816 & 4132154 & n.m. & 27.0 & 8.85 & 5 & 1535 & 1045 \\
\hline 7 & C.da Fiumefreddo & 481676 & 4131444 & n.m. & 21.1 & 7.49 & 201 & 438 & 481 \\
\hline 8 & Serravalle & 485277 & 4132994 & n.m. & 22.8 & 7.95 & 170 & 436 & 531 \\
\hline 9 & C.da Covoni & 475146 & 4130913 & 230 & 27.4 & 6.48 & -37 & 713 & 6490 \\
\hline 10 & C.da Fondachello & 498268 & 4134086 & n.m. & 23.3 & 9.22 & 200 & 715 & 800 \\
\hline 11 & C.da Valsavoia & 498218 & 4132911 & n.m. & 22.2 & 8.16 & 252 & 570 & 480 \\
\hline 12 & Portella Papera & 493908 & 4132940 & 300 & 31.7 & 7.90 & 140 & 2261 & 2010 \\
\hline 13 & Monte Ranné & 492252 & 4132630 & n.m. & 33.1 & 7.48 & 115 & 2672 & 1755 \\
\hline 14 & Rizzo & 489252 & 4130009 & n.m. & 28.8 & 8.75 & 130 & 1532 & 1480 \\
\hline 15 & C.da Santorello & 491722 & 4131565 & n.m. & 33.7 & 7.15 & -280 & 2770 & 2350 \\
\hline 16 & Tirirò & 487752 & 4131609 & n.m. & 28.4 & 9.06 & 88.5 & 2389 & 1275 \\
\hline 17 & C.da Vanchella & 475516 & 4132328 & n.m. & 28.5 & 7.02 & -100 & 3539 & 1840 \\
\hline 18 & Cosentino & 486612 & 4133245 & n.m. & 21.5 & 8.04 & 96.8 & 678 & 706 \\
\hline 19 & SATER & 486997 & 4134140 & n.m. & 20.5 & 8.11 & 93.8 & 1003 & 731 \\
\hline 20 & C.da Arcimusa & 487533 & 4135650 & 200 & 21.6 & 8.60 & 105 & 975 & 837 \\
\hline 21 & Rapisarda & 488777 & 4129424 & n.m. & 23.9 & 8.05 & 270 & 1315 & 507 \\
\hline 22 & Poggio Pizzuto & 475385 & 4128718 & n.m. & 26.5 & 6.00 & 87.5 & 2481 & 2180 \\
\hline 23 & $\begin{array}{c}\text { Catania Poggio } \\
\text { Pizzuto }\end{array}$ & 474760 & 4128318 & n.m. & 24.2 & 8.26 & 20 & 1287 & 733 \\
\hline
\end{tabular}

Table 1 (continued) 
Geothermal systems in east Sicily

\begin{tabular}{|c|c|c|c|c|c|c|c|c|c|}
\hline Sample Id & Site & $\begin{array}{c}\mathrm{Na} \\
\mathrm{mg} / \mathrm{L}\end{array}$ & $\begin{array}{c}\mathrm{K} \\
\mathrm{mg} / \mathrm{L}\end{array}$ & $\begin{array}{c}\mathrm{Ca} \\
\mathrm{mg} / \mathrm{L}\end{array}$ & $\begin{array}{c}\mathrm{Mg} \\
\mathrm{mg} / \mathrm{L}\end{array}$ & $\begin{array}{c}\mathrm{Cl} \\
\mathrm{mg} / \mathrm{L}\end{array}$ & $\begin{array}{c}\mathrm{SO}_{4} \\
\mathrm{mg} / \mathrm{L}\end{array}$ & $\begin{array}{c}\mathrm{HCO}_{3} \\
\mathrm{mg} / \mathrm{L}\end{array}$ & $\begin{array}{c}\mathrm{CO}_{3} \\
\mathrm{mg} / \mathrm{L}\end{array}$ \\
\hline 1 & Sessa & 624 & 12 & 21 & 27 & 100 & 499 & 1431 & 23 \\
\hline 2 & Scala Bianca & 20 & 3.3 & 47 & 16 & 20 & 18 & 223 & \\
\hline 3 & Pignatazza & 96 & 5.7 & 4.5 & 3.7 & 32 & 46 & 198 & 17 \\
\hline 4 & Via Simeto & 61 & 7.1 & 61 & 34 & 61 & 123 & 348 & \\
\hline 5 & Motta & 242 & 17 & 84 & 52 & 111 & 302 & 851 & \\
\hline 6 & Vita & 254 & 8.8 & 90 & 26 & 95 & 227 & 809 & 20 \\
\hline 7 & C.da Fiumefreddo & 34 & 3.8 & 49 & 20 & 30 & 30 & 253 & \\
\hline 8 & Serravalle & 79 & 6.0 & 21 & 15 & 67 & 28 & 204 & \\
\hline 9 & C.da Covoni & 420 & 22 & 600 & 368 & 1820 & 131 & 1349 & \\
\hline 10 & C.da Fondachello & 200 & 6.6 & 2.7 & 1.8 & 56 & 39 & 388 & \\
\hline 11 & C.da Valsavoia & 134 & 9.5 & 5.3 & 11 & 37 & 22 & 333 & \\
\hline 12 & Portella Papera & 526 & 27 & 20 & 16 & 110 & 485 & 1071 & \\
\hline 13 & Monte Ranné & 529 & 23 & 108 & 30 & 81 & 789 & 1108 & \\
\hline 14 & Rizzo & 397 & 11 & 3.1 & 1.6 & 115 & 386 & 601 & 17 \\
\hline 15 & C.da Santorello & 578 & 37 & 65 & 40 & 325 & 505 & 1211 & \\
\hline 16 & Tirirò & 610 & 17 & 3.9 & 1.0 & 106 & 625 & 1010 & 15 \\
\hline 17 & C.da Vanchella & 350 & 16 & 252 & 243 & 271 & 111 & 2291 & \\
\hline 18 & Cosentino & 130 & 8.9 & 34 & 32 & 175 & 27 & 253 & \\
\hline 19 & SATER & 200 & 5.8 & 35 & 42 & 232 & 70 & 381 & \\
\hline 20 & C.da Arcimusa & 168 & 9.1 & 41 & 53 & 222 & 73 & 363 & \\
\hline 21 & Rapisarda & 256 & 11 & 22 & 35 & 115 & 254 & 601 & \\
\hline 22 & Poggio Pizzuto & 415 & 21 & 143 & 35 & 173 & 313 & 1382 & \\
\hline 23 & $\begin{array}{c}\text { Catania Poggio } \\
\text { Pizzuto }\end{array}$ & 309 & 8.1 & 7.2 & 6.9 & 72 & 219 & 650 & 11 \\
\hline
\end{tabular}

Table 1 (continued) 
Gloria Maria Ristuccia et al.

\begin{tabular}{|c|c|c|c|c|c|c|c|c|c|}
\hline Sample Id & Site & $\begin{array}{l}\mathrm{NO}_{3} \\
\mathrm{mg} / \mathrm{L}\end{array}$ & $\begin{array}{l}\mathrm{SiO}_{2} \\
\mathrm{mg} / \mathrm{L}\end{array}$ & $\begin{array}{c}\text { B } \\
\mathrm{mg} / \mathrm{L}\end{array}$ & $\begin{array}{c}F \\
\mathrm{mg} / \mathrm{L}\end{array}$ & $\begin{array}{c}\mathrm{Sc} \\
\mu \mathrm{g} / \mathrm{L}\end{array}$ & $\begin{array}{c}\mathrm{Cr} \\
\mu \mathrm{g} / \mathrm{L}\end{array}$ & $\begin{array}{c}\mathrm{V} \\
\mu \mathrm{g} / \mathrm{L}\end{array}$ & $\begin{array}{c}\text { Mn tot } \\
\mu \mathrm{g} / \mathrm{L}\end{array}$ \\
\hline 1 & Sessa & b.d.l. & 15 & 0.01 & 0.84 & 0.14 & 4.8 & 3.2 & 7.9 \\
\hline 2 & Scala Bianca & 9.7 & 17 & b.d.l. & 0.23 & 0.41 & b.d.l. & 24 & 1.3 \\
\hline 3 & Pignatazza & b.d.l. & 17 & b.d.l. & 0.21 & 0.03 & b.d.l. & 2.2 & 3.0 \\
\hline 4 & Via Simeto & 16 & 21 & b.d.l. & 0.11 & 0.13 & b.d.l. & 17 & 0.56 \\
\hline 5 & Motta & b.d.l. & 26 & b.d.l. & 1.7 & 0.46 & b.d.l. & 0.07 & 16 \\
\hline 6 & Vita & 7.2 & 28 & 0.03 & 0.32 & 0.05 & 2.3 & 4.8 & 1.6 \\
\hline 7 & C.da Fiumefreddo & 18 & 26 & b.d.l. & 0.40 & b.d.l. & b.d.l. & 31 & 0.94 \\
\hline 8 & Serravalle & 15 & 24 & 0.02 & 0.51 & b.d.l. & b.d.l. & 36 & 0.02 \\
\hline 9 & C.da Covoni & b.d.l. & 47 & 0.71 & 2.2 & 2.1 & b.d.l. & 0.44 & 271 \\
\hline 10 & C.da Fondachello & 22 & 12 & b.d.l. & 0.44 & b.d.l. & 5.8 & 148 & 0.14 \\
\hline 11 & C.da Valsavoia & 19 & 25 & b.d.l. & 0.17 & b.d.l. & 5.1 & 40 & 0.01 \\
\hline 12 & Portella Papera & 6.6 & 49 & 0.04 & 0.44 & 0.26 & 4.8 & 24 & 1.8 \\
\hline 13 & Monte Ranné & 3.8 & 43 & 0.04 & 0.82 & b.d.l. & 2.3 & 1.8 & 9 \\
\hline 14 & Rizzo & 0.40 & 11 & 0.07 & 0.17 & b.d.l. & b.d.l. & 3.1 & 0.68 \\
\hline 15 & C.da Santorello & 9.2 & 59 & 0.21 & 1.1 & 0.05 & b.d.l. & 0.03 & 2.5 \\
\hline 16 & Tirirò & b.d.l. & 14 & 0.05 & 1.1 & b.d.l. & b.d.l. & 3.8 & 0.26 \\
\hline 17 & C.da Vanchella & 5.3 & 90 & 0.11 & b.d.l. & 1.3 & b.d.l. & 0.27 & 106 \\
\hline 18 & Cosentino & 18 & 30 & 0.17 & 0.34 & b.d.l. & b.d.l. & 40 & 0.23 \\
\hline 19 & SATER & 37 & 29 & 0.20 & 0.38 & b.d.l. & b.d.l. & 60 & 0.14 \\
\hline 20 & C.da Arcimusa & 46 & 28 & 0.15 & 0.38 & b.d.l. & b.d.l. & 28 & 0.36 \\
\hline 21 & Rapisarda & 21 & 20 & 0.04 & 0.36 & b.d.l. & b.d.l. & 21 & 0.09 \\
\hline 22 & Poggio Pizzuto & b.d.l. & 36 & 0.08 & 0.34 & b.d.l. & b.d.l. & 4.6 & 123 \\
\hline 23 & $\begin{array}{c}\text { Catania Poggio } \\
\text { Pizzuto }\end{array}$ & 3.8 & 26 & 0.02 & 0.27 & b.d.l. & b.d.l. & 1.4 & 0.98 \\
\hline
\end{tabular}

Table 1 (continued) 
Geothermal systems in east Sicily

\begin{tabular}{|c|c|c|c|c|c|c|c|}
\hline Sample Id & Site & $\begin{array}{c}\text { Fe tot } \\
\mu \mathrm{g} / \mathrm{L}\end{array}$ & $\begin{array}{c}\text { Co } \\
\mu \mathrm{g} / \mathrm{L}\end{array}$ & $\begin{array}{l}\text { Ni tot } \\
\mu \mathrm{g} / \mathrm{L}\end{array}$ & $\begin{array}{c}\mathrm{Cu} \\
\mu \mathrm{g} / \mathrm{L}\end{array}$ & $\begin{array}{l}\text { Zn tot } \\
\mu \mathrm{g} / \mathrm{L}\end{array}$ & $\begin{array}{r}\mathrm{Cd} \\
\mu \mathrm{g} / \mathrm{L}\end{array}$ \\
\hline 1 & Sessa & 43 & 0.20 & 3.9 & 20 & 33 & 0.01 \\
\hline 2 & Scala Bianca & 99 & 0.22 & 0.54 & 1.2 & 20 & 0.02 \\
\hline 3 & Pignatazza & 65 & 0.10 & 0.30 & 3.6 & 15 & b.d.l. \\
\hline 4 & Via Simeto & 124 & 0.14 & 0.68 & 2.1 & 6.4 & b.d.l. \\
\hline 5 & Motta & 183 & 0.07 & 0.07 & 5.9 & 1.8 & b.d.l. \\
\hline 6 & Vita & 137 & 0.09 & 0.99 & 6.3 & 37 & b.d.l. \\
\hline 7 & C.da Fiumefreddo & 91 & 0.09 & 0.50 & 4.4 & 10 & b.d.l. \\
\hline 8 & Serravalle & 26 & 0.04 & 0.12 & 2.7 & 0.34 & b.d.l. \\
\hline 9 & C.da Covoni & 7.7 & 0.36 & 1.0 & 11 & 3.4 & 0.67 \\
\hline 10 & C.da Fondachello & 23 & 0.04 & b.d.l. & 6.4 & b.d.l. & 0.11 \\
\hline 11 & C.da Valsavoia & 8.6 & 0.03 & b.d.l. & 4.4 & b.d.l. & 1.6 \\
\hline 12 & Portella Papera & 31 & 0.04 & 1.9 & 12 & 1.3 & b.d.l. \\
\hline 13 & Monte Ranné & 139 & 0.22 & 3.1 & 8.1 & 3.3 & b.d.l. \\
\hline 14 & Rizzo & 21 & 0.03 & 1.4 & 11 & b.d.l. & b.d.l. \\
\hline 15 & C.da Santorello & 209 & 0.03 & 0.63 & 12 & 3.5 & b.d.l. \\
\hline 16 & Tirirò & b.d.l. & 0.01 & 0.96 & 11 & 3.1 & b.d.l. \\
\hline 17 & C.da Vanchella & 0.76 & 0.09 & 0.02 & 8.4 & 83 & b.d.l. \\
\hline 18 & Cosentino & 55 & 0.02 & b.d.l. & 3.8 & 4.9 & b.d.l. \\
\hline 19 & SATER & 46 & 0.04 & 0.20 & 7.0 & 3.8 & b.d.l. \\
\hline 20 & C.da Arcimusa & 55 & 0.06 & b.d.l. & 4.3 & 0.24 & b.d.l. \\
\hline 21 & Rapisarda & 25 & 0.03 & 0.24 & 5.8 & 8.9 & b.d.l. \\
\hline 22 & Poggio Pizzuto & 1.9 & 0.23 & 1.2 & 12 & 930 & b.d.l. \\
\hline 23 & $\begin{array}{c}\text { Catania Poggio } \\
\text { Pizzuto }\end{array}$ & 16 & 0.01 & 0.51 & 7.7 & 9.7 & b.d.l. \\
\hline
\end{tabular}

Table 1. Chemical and physico-chemical parameters analyzed in the sampled waters. n.m. = not measured. b.d.l. = below detection limit. 


\section{Gloria Maria Ristuccia et al.}

$\mathrm{D} / \mathrm{H}$ isotopic analyses of water were performed using the Kendall and Coplen [1985] technique (reaction with $\mathrm{Zn}$ at $450^{\circ} \mathrm{C}$ ), while ${ }^{18} \mathrm{O} /{ }^{16} \mathrm{O}$ analyses were carried out by the $\mathrm{CO}_{2}$-water equilibration technique [Epstein and Mayeda, 1953]. The isotopic composition of total dissolved inorganic C (TDIC) was determined by means of the method proposed by Capasso et al. [1998]. Measurements were carried out using a Finnigan Delta Plus mass spectrometer (Hydrogen) and an automatic preparation system coupled with an AP 2003 IRMS (Oxygen). The results are reported in $\delta$ per mil units vs. the V-SMOW standard for the water isotopes and $\delta^{13} \mathrm{C}, \delta$ per mil vs. V-PDB standard for the TDIC. The standard deviations of the measurements were approximately $21 \delta$ for the $\mathrm{D} / \mathrm{H}$ and $20.2 \delta$ for the ${ }^{18} \mathrm{O} /{ }^{16} \mathrm{O}$ and ${ }^{13} \mathrm{C} /{ }^{12} \mathrm{C}$.

\section{Results and interpretation of data}

\subsection{Groundwater isotope composition}

The results of oxygen and hydrogen (deuterium) isotope analyses are shown in Table 2 . The studied waters show $\delta^{18} \mathrm{O}$ values in the range between -6.00 and $-5.03 \%$ and $\delta \mathrm{D}$ between -39.5 and $-25.0 \%$. In the $\delta \mathrm{D}$ vs $\delta^{18} \mathrm{O}$ plot of Figure 3, the water isotope composition of our samples for the most part falls between the Global Meteoric Water Line (GMWL in Figure 3) defined by Craig [1961, 1963] and the East Mediterranean Meteoric Water Line (EMMWL in Figure 3) defined by Gat and Carmi [1970]. In particular, our samples fall in an even narrower range defined by the GWML and the Local Meteoric Water Line (LMWL) calculated for the Hyblean area by Grassa [2002] based on the equation:

$$
\delta \mathrm{D}=6.14 \delta^{18} \mathrm{O}+6.8
$$

The low value, lower than 8 , of the slope in eq. (1) indicates that some disequilibrium processes occurred during or after the condensation of water [Gonfiantini, 1986]. This could be due to partial evaporation of rain water during its fall on the ground surface [Grassa, 2002]. However, only a few samples fall close to the LMWL, whereas the composition of almost the totality of our samples shows a further isotopic shift towards the right of it defining a new line whose slope is even lower than the LMWL, according to the following equation:

$$
\delta \mathrm{D}=5.5 \delta^{18} \mathrm{O}-2.93
$$

This result suggests that the studied waters underwent further isotopic fractionation due to evaporation during or after their infiltration in the subsoil, which is common in areas with arid or semi-arid climate conditions [Zimmerman et al., 1967; Leontiadis, 1996], as is the case of the portions of the studied Hyblean region characterized by lower elevation topography [Grassa, 2002].

The observed $\delta^{18} \mathrm{O}$ positivization (Figure 3) could be also caused by ionic exchange processes, typical of thermal areas, between the oxygen of water and that of the host rocks of the aquifer.

A further process causing $\delta^{18} \mathrm{O}$ positivization could be possible mixing between fresh groundwater and deep brines, as presumed in samples with higher water temperature (e.g., samples 1, 5, 6, 9, 13). Brines and more generally connate waters are actually characterized by more positive $\delta^{18} \mathrm{O}$ values [Sheppard, 1986]. However, because the aqueous system in our study has low thermal conditions $\left(<120^{\circ} \mathrm{C}\right)$, water evaporation processes are likely to have the highest impact in determining the observed isotopic shift.

Table 2 also shows the isotopic composition of the Total Dissolved Inorganic Carbon (TDIC, expressed as $\delta^{13} \mathrm{C}_{\text {TDIC }}$ in our samples, which ranges between $-13.9 \%$ and $+5.4 \%$. Such a wide range of values suggests that dissolved carbon in our waters derives from several different carbon sources. In our cases, carbon should come from dissolution of carbonatic minerals - largely present in the study area, dissolution of atmospheric $\mathrm{CO}_{2}$, biogenic $\mathrm{CO}_{2}$ and inorganic $\mathrm{CO}_{2}$. The latter seemingly derives from deep sources, like thermal decarbonation of limestone and/or mantle degassing through the many deep regional tectonic faults [Grassa, 2002]. Massive emissions of mantlederived $\mathrm{CO}_{2}$ at the surface occur in a small area near the town of Palagonia (Figure 2), where this gas is actually extracted and bottled for industrial and medical uses [De Gregorio et al., 2002; Giammanco et al., 2007]. Caracausi et al. [2003a, 2003b] showed that, despite the great distance between this area and Mt. Etna volcano (about $40 \mathrm{~km}$ 


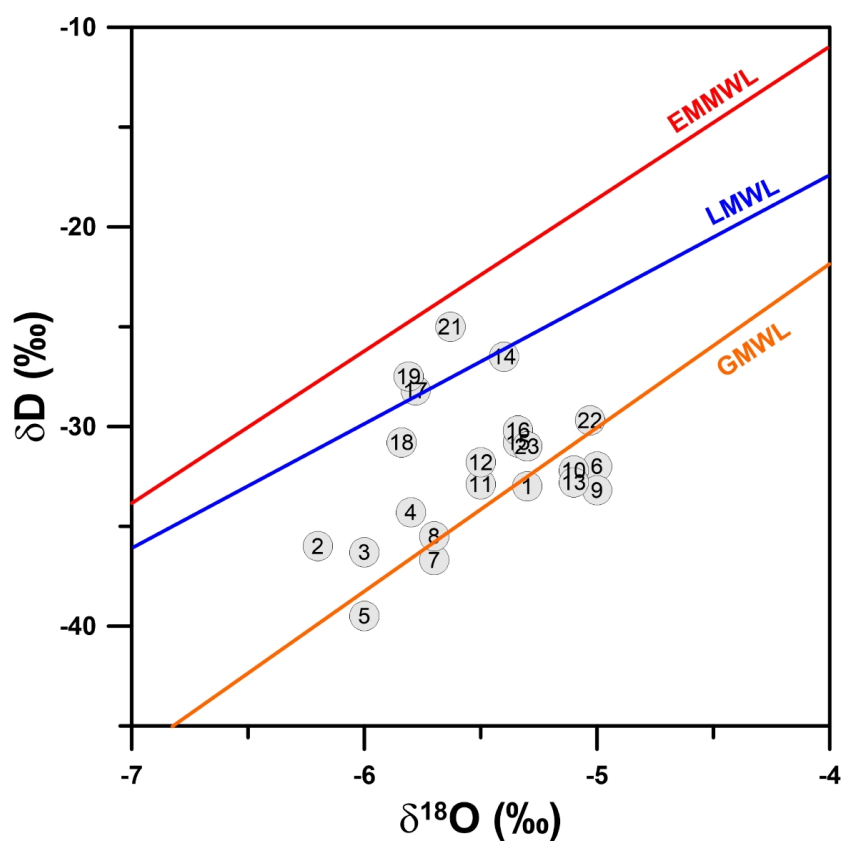

Figure 3. Correlation plot of $\delta^{18} \mathrm{O}$ vs. Deuterium of water (all values in $\delta \%$ o vs. SMOW). EMMWL = East Mediterranean Meteoric Water Line; LMWL = Local Meteoric Water Line of Grassa (2002); GMWL = Global Meteoric Water Line.

\begin{tabular}{|c|c|c|c|}
\hline Sample & $\delta^{18} 0$ & $\delta \mathrm{D}$ & TDIC \\
\hline 1 & -5.30 & -33.0 & -4.28 \\
\hline 2 & -6.20 & -36.0 & -13.67 \\
\hline 3 & -6.00 & -36.3 & -11.89 \\
\hline 4 & -5.80 & -34.3 & -13.18 \\
\hline 5 & -6.00 & -39.5 & -7.08 \\
\hline 6 & -5.00 & -32.0 & -13.90 \\
\hline 7 & -5.70 & -36.7 & -13.27 \\
\hline 8 & -5.70 & -35.5 & -12.37 \\
\hline 9 & -5.00 & -33.2 & 2.34 \\
\hline 10 & -5.10 & -32.2 & -11.37 \\
\hline 11 & -5.50 & -32.9 & -4.52 \\
\hline 12 & -5.50 & -31.8 & -8.16 \\
\hline 13 & -5.10 & -32.8 & n.d. \\
\hline 14 & -5.40 & -26.5 & -10.37 \\
\hline 15 & -5.34 & -30.8 & -3.84 \\
\hline 16 & -5.34 & -30.2 & -7.39 \\
\hline 17 & -5.78 & -28.2 & 5.41 \\
\hline 18 & -5.84 & -30.8 & -13.07 \\
\hline 19 & -5.81 & -27.5 & -13.29 \\
\hline 20 & n.d. & -27.6 & -13.91 \\
\hline 21 & -5.63 & -25.0 & -12.42 \\
\hline 22 & -5.03 & -29.7 & -2.19 \\
\hline 23 & -5.30 & -31.0 & -9.98 \\
\hline
\end{tabular}

Table 2. Results of water isotopic composition; (n.d. = not determined). 


\section{Gloria Maria Ristuccia et al.}

from its SW geological limit), the anomalous local $\mathrm{CO}_{2}$ outgassing is to be related with a deep magmatic source common to that feeding Mt. Etna activity. In particular, an evident synchronism was observed in several occasions between chemical and isotopic changes of gases emitted from the Palagonia area and those emitted from other high-degassing sites on and around Mt. Etna before major Etna eruptions [Caracausi et al., 2003b]. Lastly, Grassa [2002] showed that the $\delta^{13} \mathrm{C}_{\mathrm{CO} 2}$ values of dissolved carbon in the waters with the highest $\mathrm{P}_{\mathrm{CO} 2}$ values $\left(\log \mathrm{P}_{\mathrm{CO} 2} \cong 0.5\right)$ were close to $-1 \%$ and hence therefore within the typical range of magmatic $\mathrm{CO}_{2}$ found at Mt. Etna [Allard, 1986; Giammanco et al., 1998a, 1998b; Pecoraino and Giammanco, 2005], and the corresponding isotopic ratios of dissolved $\mathrm{He}(\mathrm{R} / \mathrm{Ra}>1)$ were compatible with a mantle origin.

No analytical data on dissolved $\mathrm{CO}_{2}$ were collected during the present investigation. However, it is well known that the higher the $\mathrm{CO}_{2}$ concentration in water, the higher the $\mathrm{HCO}_{3}{ }^{-}$contents and the lower the $\mathrm{pH}$ values. Therefore, the strong positive correlation found in the $\delta^{13} \mathrm{C}_{\mathrm{TDIC}}$ Vs. $\left(\mathrm{HCO}_{3}{ }^{-}+\mathrm{CO}_{3}{ }^{-}\right)$diagram (Figure 4) indicates the relevant contribution of "heavy" inorganic $\mathrm{CO}_{2}$, likely from mantle degassing, to our groundwater samples. Some $\delta^{13} \mathrm{C}_{\text {TDIC }}$ values, up to $+5.41 \%$, are much higher than the typical range for magmatic-derived $\mathrm{CO}_{2}$, but this positive isotopic shift of TDIC can be explained in terms of strong interaction between deep magmatic fluids, rich in $\mathrm{CO}_{2}$, and hydrothermal aquifers at $50<\mathrm{T}^{\circ}<100^{\circ} \mathrm{C}$ (assuming a pristine $\delta^{13} \mathrm{C}_{\mathrm{CO} 2}$ value of $-1 \%$ ). In those cases, according to Mook et al. [1974] and Inguaggiato et al. [2000], the fractionation factor in water between carbon of $\mathrm{CO}_{2}$ gas and that of dissolved $\mathrm{HCO}_{3}{ }^{-}$favors enrichment of the heavier isotope in the TDIC.

\subsection{Groundwater chemistry}

The analytical results of our survey are reported in Table 1 . Water temperature values were in general slightly higher than those generally found in southeast Sicily [CNR-PFE, 1982; Battaglia et al., 1991; Ristuccia et al., 2019], having an average of $26^{\circ} \mathrm{C}$ and a maximum of $40.1^{\circ} \mathrm{C}$. This confirms the presence of a localized geothermal anomaly, as already suggested by CNR-PFE [1982] and Battaglia et al. [1991]. Water conductivity, TDS and pH values are highly variable, being in the ranges $385-6490 \mu \mathrm{S} / \mathrm{cm}, 357-4713 \mathrm{mg} / \mathrm{L}$ and 6.00-9.25, respectively, the lowest values being measured in samples 5, 9, 17, and 22 (Palagonia area; Figure 2).

As previously described, this area is known for the presence of many strong $\mathrm{CO}_{2}$ emissions, which explain, in particular, the relatively low pH values [Grassa, 2002; Caracausi et al., 2003a, 2003b]. Furthermore, the same samples and sample 15 showed the most negative values of $\mathrm{Eh}(-362$ to $-37 \mathrm{mV}$ ), likely because of strong input of deep reducing gases. The square Langelier-Ludwig diagram [Langelier and Ludwig, 1942] for the analyzed samples (Figure 5) shows three distinct groups of waters:

i) Typical groundwater, having bicarbonate-alkaline-earth composition due to interaction between rainwater and local rocks (essentially carbonate rocks and interbedded basic volcanics);

ii) Bicarbonate-alkaline waters, most probably resulting from alkali enrichment due to marked interaction between groundwater and deep $\mathrm{CO}_{2}$, probably associated with high-enthalpy fluids. Actually, the plots of Figure 6 show a nice positive correlation trend between water temperature and bicarbonate, sodium and chlorine contents in our samples. Water-gas-rock interaction produces conversion of plagioclase of mafic volcanics into clays, thus turning the original water composition into bicarbonate-alkaline. Water gets enriched in $\mathrm{Na}^{+}$and $\mathrm{HCO}_{3}{ }^{-}$, whereas the $\mathrm{Ca}^{2+}$ concentration is lowered due to the low solubility of calcite and both $\mathrm{K}^{+}$and $\mathrm{Mg}^{2+}$ are trapped by clays [Ellis and Mahon, 1977]. Further support to the above hypothesis is given by the high values of $\mathrm{Na}^{+} / \mathrm{Cl}^{-}$, which is higher than the typical seawater composition. However, some of the samples with high $\mathrm{Na}^{+}$content and relatively low $\mathrm{Na}^{+} / \mathrm{Cl}^{-}$(samples 9, 17, 15), a contribution from deep waters rich in $\mathrm{Cl}^{-}$cannot be ruled out. The concomitance of water-gas-rock alteration and of mixing between groundwater and geothermal brine would be supported by the $\mathrm{Cl}^{-} / \mathrm{HCO}_{3}{ }^{-}$correlation plot (Figure 7), where two distinct groups (A and B in the Figure) with two different ratios can be observed. Higher $\mathrm{Cl}^{-} / \mathrm{HCO}_{3}{ }^{-}$values are typical of deep brines and actually they occur in the samples that show also a higher $\mathrm{Cl}^{-} / \mathrm{T}^{\circ}$ ratio (Figure 6c);

iii) Sample n. 9 is the only one with a sulfate-chlorine-alkaline earth composition. Furthermore, this sample shows the highest TDS value, together with very high $\mathrm{Cl}^{-}, \mathrm{Na}^{+}$and $\mathrm{K}^{+}$contents, as well as slight thermal conditions (see Table 1). Sulphate enrichment should derive from oxidation of $\mathrm{H}_{2} \mathrm{~S}$ during condensation of deep steam in a brine-type fluid. This suggests a deep and slow circulation of the original fluid, causing its partial cooling and more marked ionic exchange with the host rocks, likely responsible for a higher degree of "maturity" of the 
geothermal fluid. The consequent loss of alkali ions together with the enrichment in alkaline-earth ions could explain the composition of this sample as well as that of samples 18, 19 and 20, as outlined above. The latter would, therefore, represent intermediate steps in the above process and hence a sort of mixture between "young geothermal brines" represented by samples 14-16 and "mature" geothermal fluids represented by sample 9 .

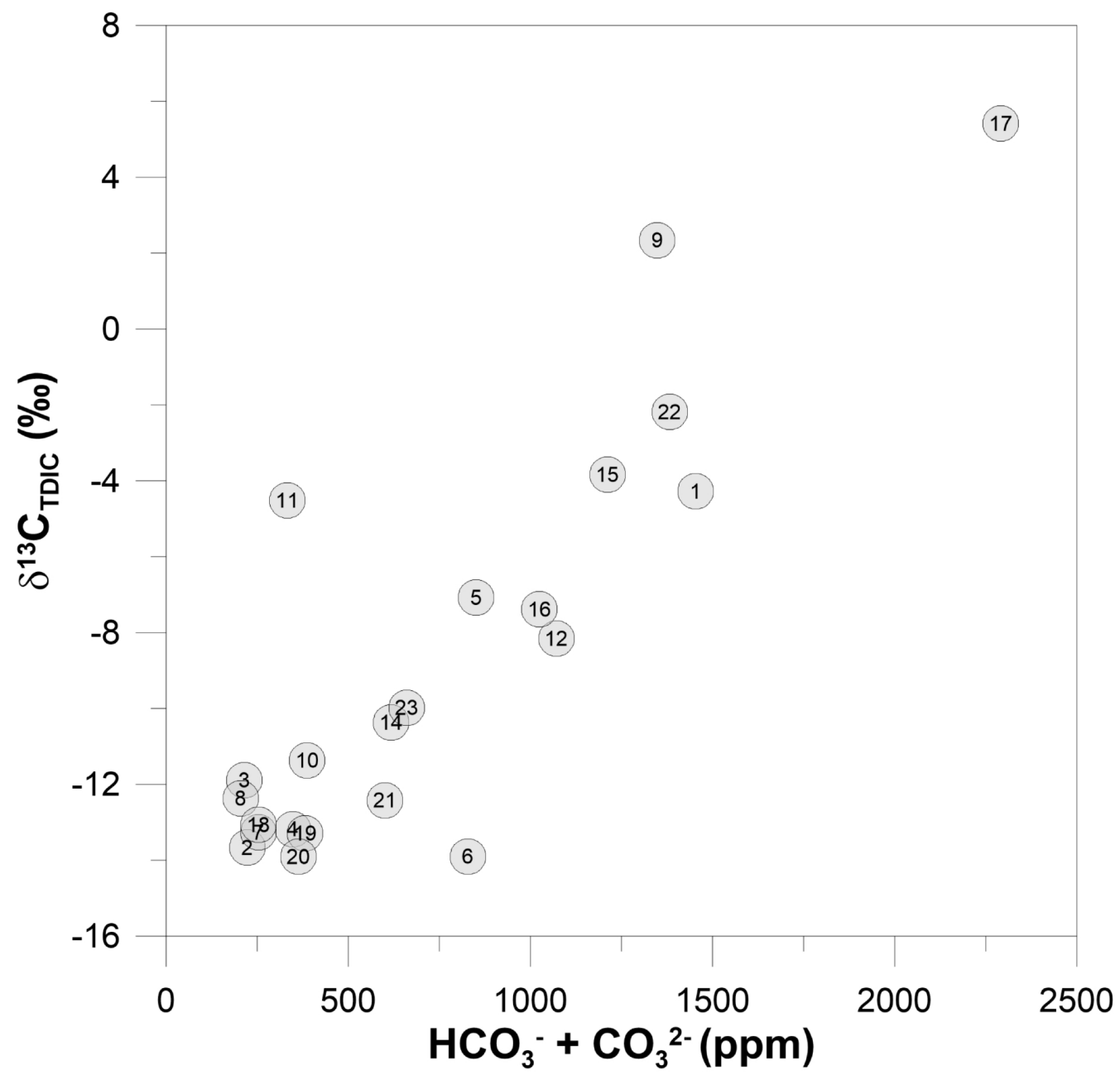

Figure 4. Correlation plot of $\delta^{13} \mathrm{C}_{\mathrm{TDIC}}$ vs $\left(\mathrm{HCO}_{3}{ }^{-}+\mathrm{CO}_{3}{ }^{2-}\right)$ values.

In the modified $\mathrm{HCO}_{3}-\mathrm{SO}_{4}$-Cl ternary diagram of Figure 8 [Giggenbach, 1988], used to classify geothermal fluids based on the major anions content, it is clearly visible that most of the samples cluster in the sector of bicarbonate waters, as typical of shallow groundwater. The diagram also shows two distinct compositional trends, respectively towards sulphate- and chlorine-rich waters (colored arrows in Figure 8). The former trend suggests mixing between shallow groundwaters and steam-heated groundwaters, whereas the latter indicates mixing with mature geothermal waters. Not surprisingly, the samples belonging to the second group are those showing possible ionic exchange in the square Langelier-Ludwig diagram of Figure 5.

During their evolution as consequence of interaction with deep $\mathrm{CO}_{2}$ and/or of mixing with brines, local groundwaters show progressively increasing salinity values. This is clearly shown by the $\mathrm{e}_{\mathrm{Na}}+\mathrm{e}_{\mathrm{K}}+\mathrm{e}_{\mathrm{Cl}}+\mathrm{e}_{\mathrm{SO} 4} \mathrm{vs}$. $\mathrm{e}_{\mathrm{Ca}}$ $+\mathrm{e}_{\mathrm{Mg}}+\mathrm{e}_{\mathrm{HCO} 3}$ correlation plot of Figure 9 [modified from Marini, 2000].

This plot is equivalent to the triangular cross-section of a compositional pyramid, whose base is represented by the square Langelier-Ludwig diagram, whose edges are the chemical concentrations of the major ions (in this case $\mathrm{Na}^{+}+$ $\mathrm{K}^{+}+\mathrm{Cl}^{-}+\mathrm{SO}_{4}{ }^{2-}$ and $\mathrm{Ca}^{2+}+\mathrm{Mg}^{2+}+\mathrm{HCO}_{3}{ }^{-}$) in eq/L or meq/L, and whose axis expresses the Total Ionic Salinity (TIS, in the same unit). In these cross-sections, and hence in the plot of Figure 9, the lines with slope -1 are isosalinity lines. 


\section{Gloria Maria Ristuccia et al.}

In this plot, it is noteworthy that all samples show in general a nice positive correlation between the two groups of elements as the salinity increases. Furthermore, samples 9 and 17 show the highest TIS values and also a compositional shift towards higher $\left[\mathrm{Ca}^{2+}+\mathrm{Mg}^{2+}+\mathrm{HCO}_{3}{ }^{-}\right]$. In the case of sample 9 this shift seems due to enrichment in $\mathrm{Ca}^{2+}+\mathrm{Mg}^{2+}$, as deduced from the results of the square Langelier-Ludwig diagram, whereas in the case of sample 17 a further enrichment in $\mathrm{HCO}_{3}{ }^{-}$can be envisaged due to interaction with $\mathrm{CO}_{2}$.

Among the trace elements (TE) analyzed, only V, Mn, Co and Cu were found in all of the samples (Table 1). A large variability of TE concentrations was in general observed in all samples. Most of the TE showed concentration ranges of more than one order of magnitude among the sampling sites and in some cases (V, Mn, Fe and Zn) even up to four orders of magnitude, thus suggesting different sources and/or sink mechanisms.

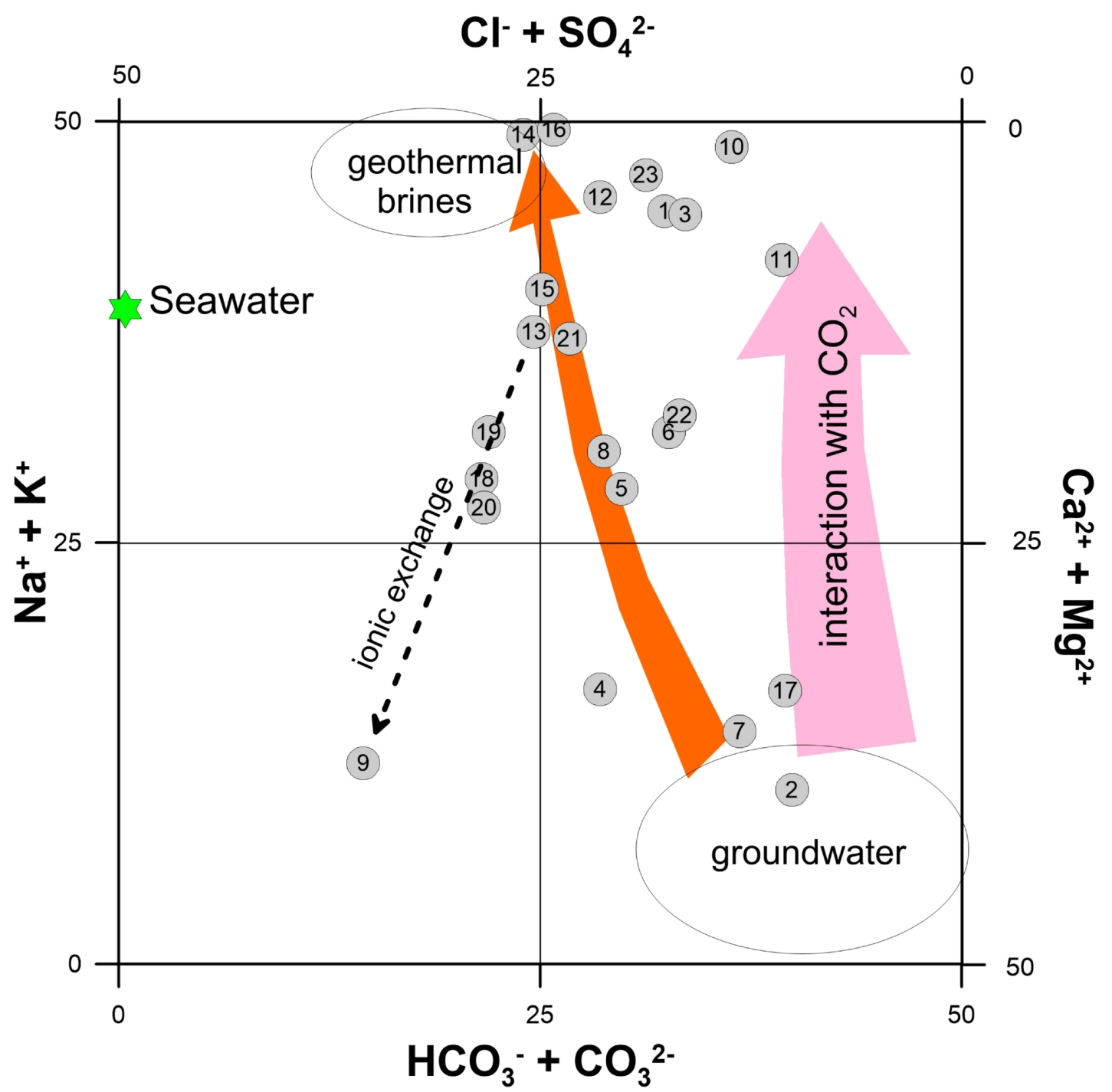

Figure 5. The square Langelier-Ludwig diagram for sampled waters. The sea water composition is highlighted with a green star. The pink arrow shows compositional changes due to interaction between typical ground water and deep $\mathrm{CO}_{2}$; the orange arrow shows compositional trends due to mixing between typical groundwater and geothermal brines; the black arrow shows compositional changes due to ionic exchange of waters after mixing with geothermal brines. 

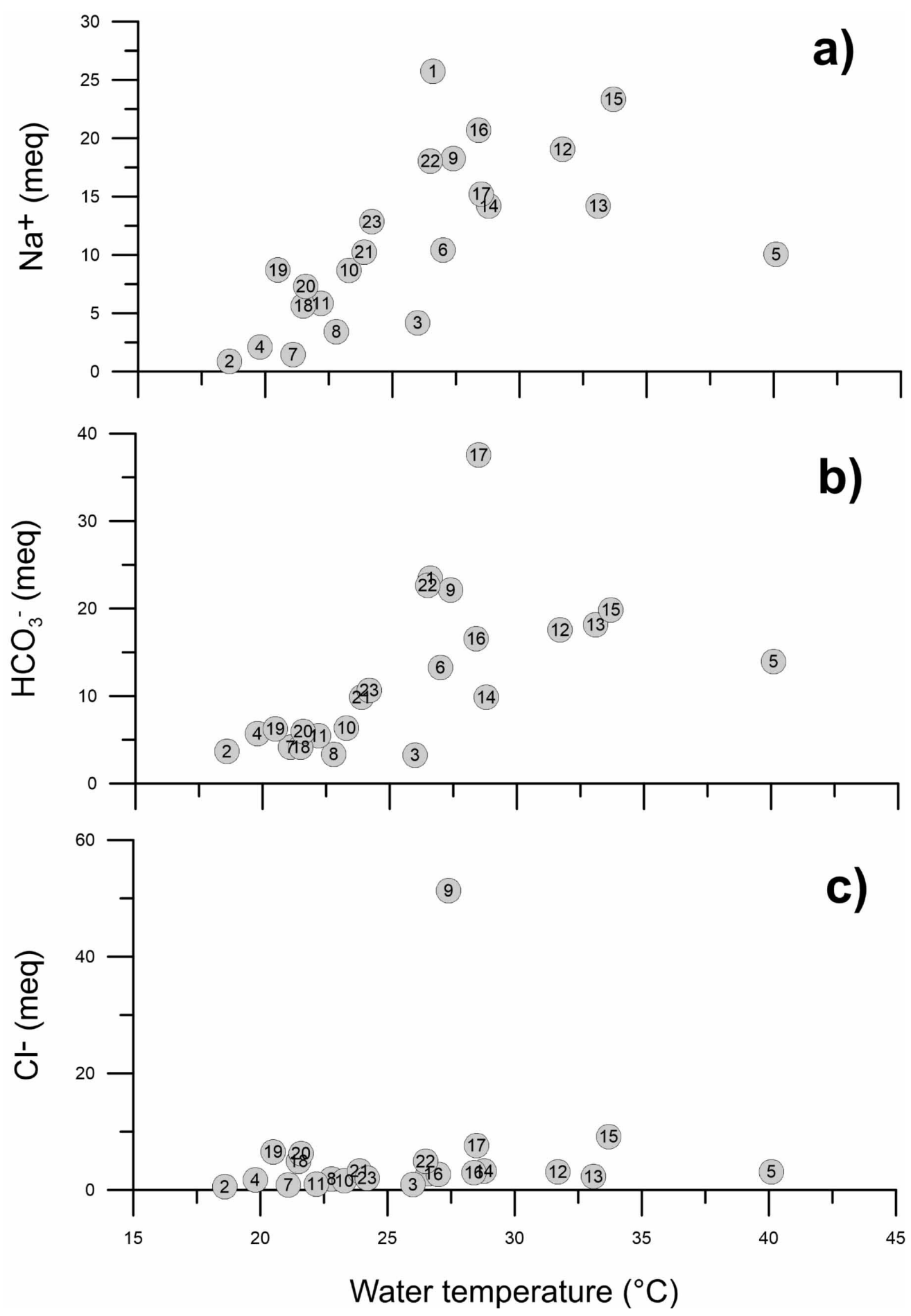

Figure 6. Correlation plots of water temperature vs. dissolved contents of (a) sodium, (b) bicarbonate and (c) chlorine. 
Gloria Maria Ristuccia et al.

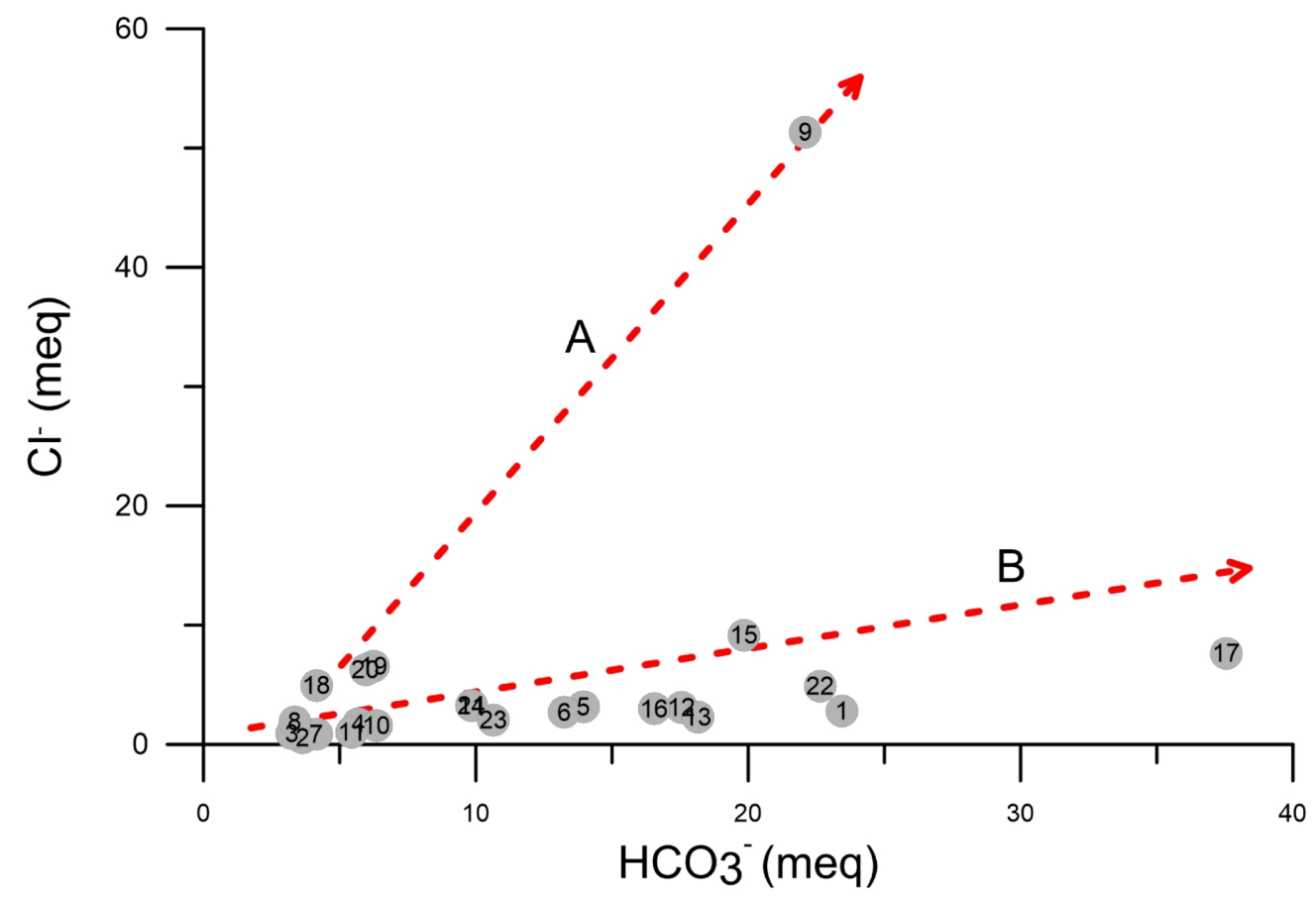

Figure 7. Correlation plot of $\mathrm{Cl}^{-}$vs. $\mathrm{HCO}_{3}{ }^{-}$concentrations in the sampled waters. Letters $\mathrm{A}$ and $\mathrm{B}$ indicate two distinct groups of samples, each one with a characteristic $\mathrm{Cl}^{-} / \mathrm{HCO}_{3}{ }^{-}$ratio (correlation trends shown by the dashed red lines with arrows).

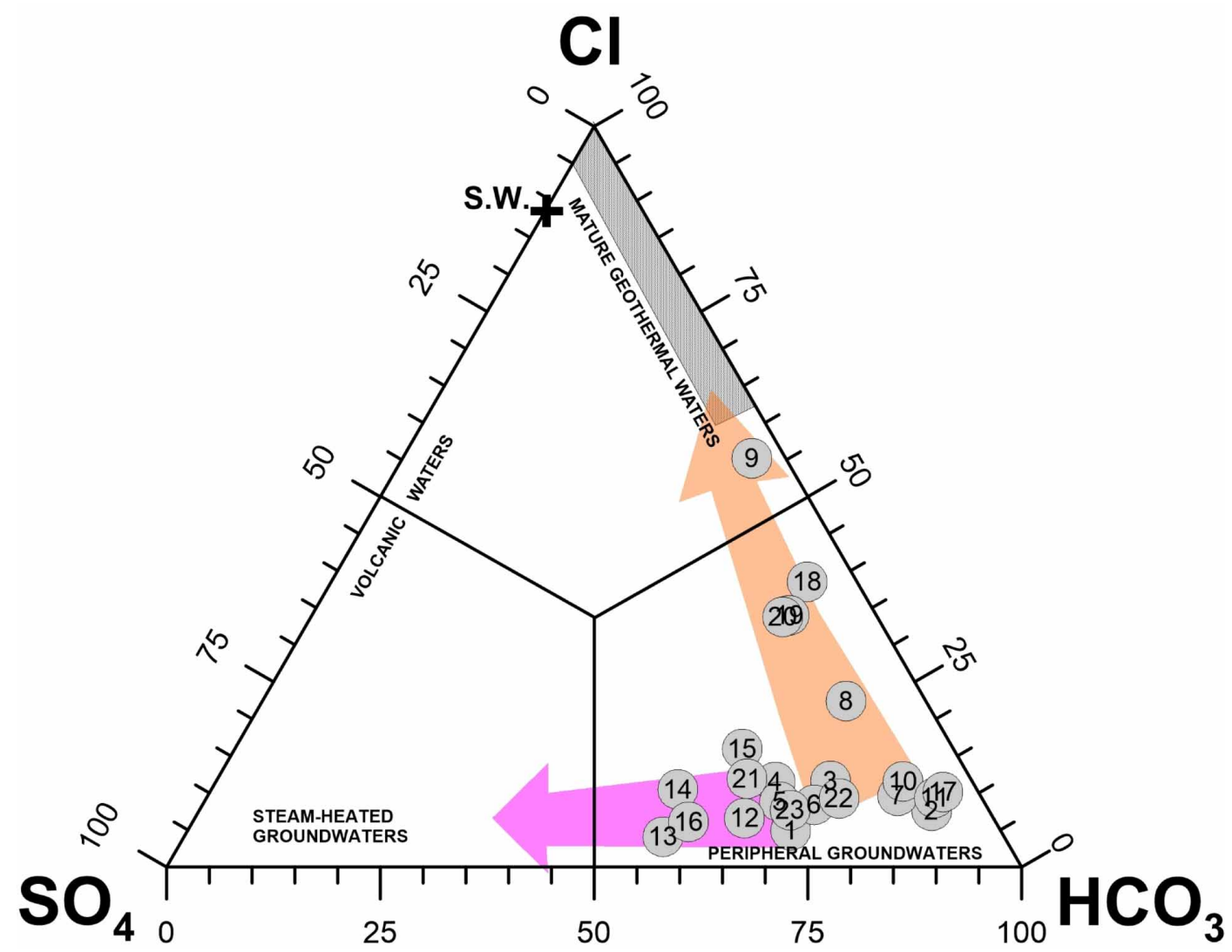

Figure 8. Modified $\mathrm{HCO}_{3}-\mathrm{SO}_{4}-\mathrm{Cl}$ ternary diagram (after Giggenbach, 1988). The light orange arrow indicates compositional trends from typical groundwater towards mature geothermal brines; the light purple arrow indicate interaction between typical groundwater and steam-heated groundwaters. S.W. = sea water composition. 


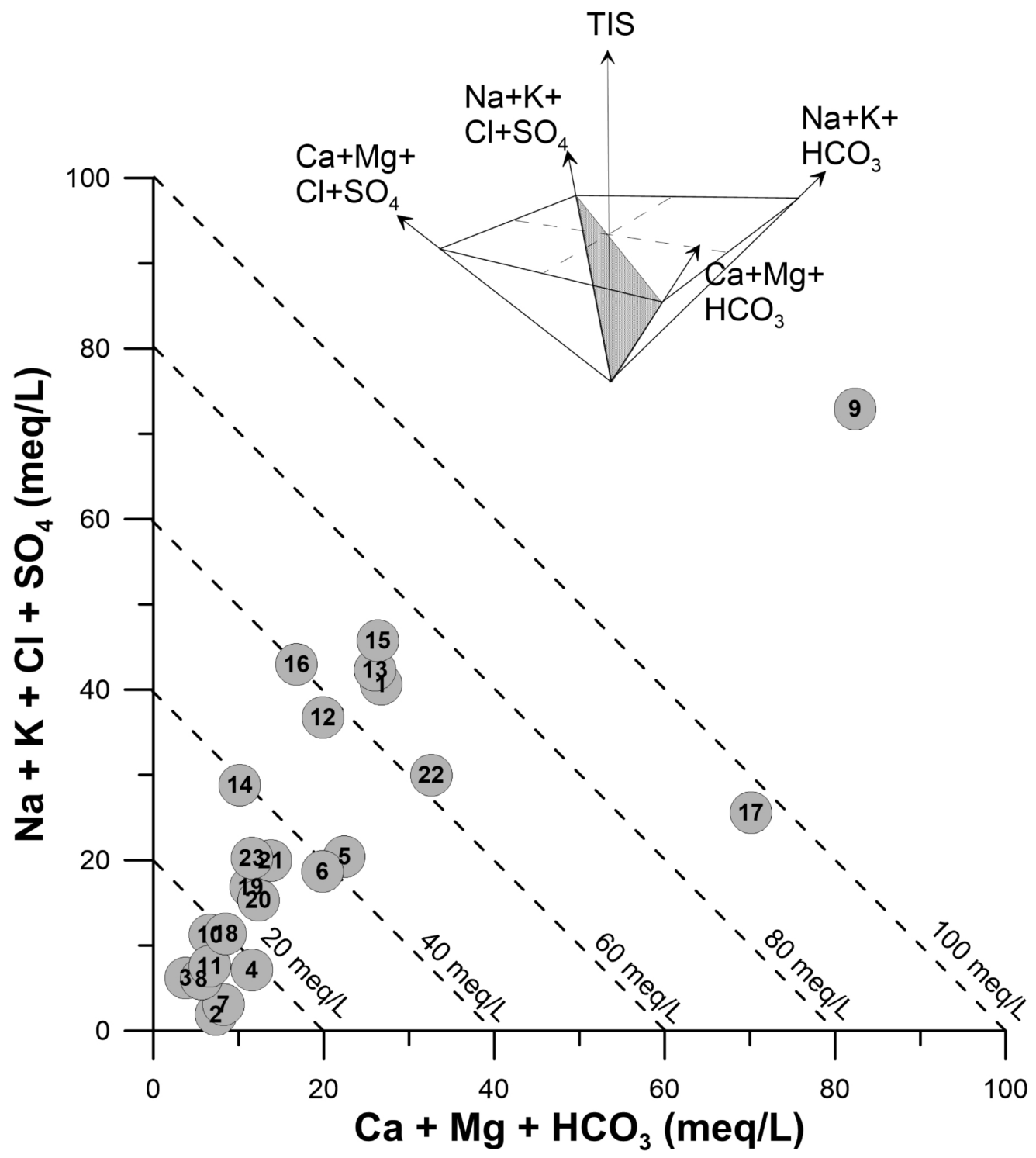

Figure 9. $e_{\mathrm{Na}}+\mathrm{e}_{\mathrm{K}}+\mathrm{e}_{\mathrm{Cl}}+\mathrm{e}_{\mathrm{SO} 4}$ vs. $\mathrm{e}_{\mathrm{Ca}}+\mathrm{e}_{\mathrm{Mg}}+\mathrm{e}_{\mathrm{HCO} 3}$ correlation plot with isosalinity lines for different kinds of waters typically found in the study area (modified from Marini, 2000). The diagram is equivalent to the triangular crosssection (shaded area) of the pyramid sketched on top.

\subsection{Principal Component Analysis}

In order to discriminate among different sources of solutes and/or different geochemical conditions in our sampled waters, we applied multivariate statistical analysis to our dataset. In particular, we used Principal Component Analysis (PCA, calculated with the pca function within the Matlab ${ }^{\circledR}$ software), taking into account only factors with eigenvalue greater than 1.5. The resulting matrix of the orthogonal factors was rotated using the Normalized Varimax procedure. Five independent factors were thus extracted, which explain $80.3 \%$ of the total variance (Table 3). The first one is responsible for $37.8 \%$ of the total variance and shows water pH negatively correlated with Conductivity, $\mathrm{Ca}, \mathrm{Mg}, \mathrm{Cl}, \mathrm{B}, \mathrm{F}, \mathrm{Sc}, \mathrm{Mn}$ and $\mathrm{Co}$. The second factor is responsible for $18.6 \%$ of the total variance and is best represented by water temperature, conductivity, $\mathrm{Na}, \mathrm{K}, \mathrm{HCO}_{3}, \mathrm{SO}_{4}, \mathrm{CO}_{3}, \mathrm{Ni}$ and $\mathrm{Cu}$. The third factor is responsible for $10.2 \%$ of the total variance and is represented by Eh and $\mathrm{Zn}$ both negatively correlated with water temperature, $\mathrm{K}, \mathrm{F}$ and $\mathrm{Fe}$. The fourth factor is responsible for $7.0 \%$ of the total variance, and is represented by 


\section{Gloria Maria Ristuccia et al.}

$\mathrm{NO}_{3}, \mathrm{Cr}, \mathrm{V}$ and $\mathrm{Cd}$. The fifth factor is responsible for $6.6 \%$ of the total variance, and is represented by $\mathrm{pH}$ and $\mathrm{CO}_{3}$, negatively correlated with $\mathrm{K}, \mathrm{HCO}_{3}, \mathrm{SiO}_{2}$ and $\mathrm{Zn}$.

\section{Factor $1 \quad$ Factor 2 Factor $3 \quad$ Factor $4 \quad$ Factor 5}

\begin{tabular}{|c|c|c|c|c|c|}
\hline $\mathrm{T}^{\circ}$ & 0.064 & 0.627 & -0.600 & 0.141 & 0.241 \\
\hline $\mathrm{pH}$ & -0.439 & -0.058 & 0.031 & -0.332 & -0.701 \\
\hline Eh & -0.245 & -0.189 & 0.718 & -0.251 & -0.392 \\
\hline Cond & 0.862 & 0.451 & -0.078 & -0.019 & 0.126 \\
\hline $\mathrm{Na}$ & 0.215 & 0.897 & -0.103 & -0.080 & 0.173 \\
\hline $\mathrm{K}$ & 0.222 & 0.644 & -0.412 & -0.030 & 0.491 \\
\hline $\mathrm{Ca}$ & 0.950 & 0.059 & 0.001 & 0.100 & 0.233 \\
\hline $\mathrm{Mg}$ & 0.917 & -0.004 & -0.028 & 0.005 & 0.269 \\
\hline $\mathrm{HCO}_{3}$ & 0.359 & 0.674 & 0.001 & 0.095 & 0.499 \\
\hline $\mathrm{SO}_{4}$ & -0.144 & 0.856 & -0.261 & 0.122 & 0.030 \\
\hline $\mathrm{NO}_{3}$ & -0.197 & -0.622 & 0.008 & -0.446 & 0.065 \\
\hline $\mathrm{Cl}$ & 0.972 & 0.050 & -0.085 & -0.063 & 0.031 \\
\hline B & 0.904 & 0.001 & -0.129 & -0.088 & 0.080 \\
\hline $\mathrm{CO}_{3}$ & -0.142 & 0.492 & 0.110 & 0.230 & -0.670 \\
\hline $\mathrm{F}$ & 0.646 & 0.309 & -0.514 & 0.013 & -0.066 \\
\hline $\mathrm{SiO}_{2}$ & 0.331 & 0.157 & -0.184 & 0.000 & 0.756 \\
\hline Sc & 0.900 & 0.029 & -0.055 & 0.025 & 0.205 \\
\hline $\mathrm{Cr}$ & -0.179 & 0.393 & 0.168 & -0.733 & -0.118 \\
\hline V & -0.198 & -0.385 & 0.146 & -0.701 & -0.039 \\
\hline $\mathrm{Mn}$ & 0.907 & 0.122 & 0.200 & 0.102 & 0.290 \\
\hline $\mathrm{Fe}$ & -0.193 & -0.027 & -0.706 & 0.321 & 0.041 \\
\hline Co & 0.660 & 0.214 & 0.295 & 0.315 & 0.008 \\
\hline $\mathrm{Ni}$ & 0.025 & 0.820 & 0.162 & 0.097 & -0.211 \\
\hline $\mathrm{Cu}$ & 0.168 & 0.910 & 0.047 & -0.093 & 0.041 \\
\hline $\mathrm{Zn}$ & -0.019 & 0.211 & 0.551 & 0.332 & 0.522 \\
\hline $\mathrm{Cd}$ & 0.332 & -0.104 & 0.139 & -0.524 & -0.018 \\
\hline
\end{tabular}

Table 3. Values of the factor scores extracted from PCA for the parameters of our analyzed waters.

The first factor is likely related with water-rock interaction in a predominantly volcanic aquifer [Giammanco et al., 1998a], where $\mathrm{Mg}$ represents dissolution of ferro-magnesian minerals (olivine, pyroxene) in $\mathrm{CO}_{2}$-rich waters, as indicated by the negative loading of $\mathrm{pH}$ in the same factor [Aiuppa et al., 2000a, 2000b]. Subsequently, these waters have probably undergone ionic exchange processes, as testified mostly by the high loadings of Ca and conductivity.

The second factor would indicate a contribution to the aquifers from brine-type geothermal fluids rising from the sedimentary basement. This stems mostly form the high loadings of water temperature, conductivity, $\mathrm{Na}, \mathrm{K}$ and $\mathrm{Cu}$.

The third factor is likely related with chemical processes driven by the redox conditions in the aquifer. Low Eh values would be related to the rise of reduced gases (mainly methane and $\mathrm{H}_{2} \mathrm{~S}$ ) from depth through faults. These reduced redox conditions are in turn responsible for the high aqueous mobility of iron (in the form of $\mathrm{Fe}^{2+}$ ), and actually this parameter shows high loadings negatively correlated with Eh. 


\section{Geothermal systems in east Sicily}

The fourth factor strongly suggest input into the aquifer of chemicals from human activities at the surface. In particular, the study area is actually strongly affected by agricultural practices related with the cultivation of oranges and this implies the use of fertilizers (as indicated by $\mathrm{NO}_{3}$ ). Furthermore, trace metals like $\mathrm{V}, \mathrm{Cr}$ and $\mathrm{Cd}$ are normally indicators of pollution from industrial wastes.

Finally, factor five describes parameters that show a strong dependency on the acidity of water, as suggested by the high loadings of $\mathrm{pH}$ and carbonates, negatively correlated with bicarbonate and $\mathrm{Zn}$.

The maps of Figure 10a to e show the geographical distribution of the scores of each factor in the study area, after interpolation of factor scores using Ordinary Kriging [Swan and Sandilands, 1995]. Factor one (Figure 10a) seems quite evenly distributed in the study area, although with a decreasing trend from west to east. This agrees well with the more frequent and marked occurrence of volcanic rocks outcrops, $\mathrm{CO}_{2}$ diffuse degassing sites and thermalized springs in the west part of the study area, where most of our sampled groundwaters come from. The highest values of this factor are found in samples 9 and, subordinately, 17 - i.e., those located closest to the high degassing mofette of Naftìa Lake and also those with some of the most peculiar chemical features among the studied waters. Factor two (Figure 10b) is the highest in the wells located along the main NE-SW-trending faults, which therefore seem to act as flow paths for the ascent of "young" geothermal brines. The lowest values of this factor occur in the samples located at the margins of the faulted zone of deep fluids ascent, most of which showed characteristics of mature geothermal waters. According to the interpretation of the chemical data of samples 9 and 17, given in section 5.2, this behavior suggests deepening and cooling of the brine-type fluids, together with their increasing interaction with the host rocks that produced the already discussed ionic exchange processes. The distribution map of factor 3 scores (Figure 10c) shows that the most extreme values are found in the sites with the strongest signs of input of geothermal/magmatic fluids into the aquifers. In particular, both the sites along the major faults in the east part of the study area and those around the town of Palagonia have the lowest score values, thus indicating a more marked influence from reducing conditions in the aquifer on the groundwater chemistry. Figure 10d shows a widespread influence of water pollution from human activities on the groundwater composition, especially in the central and west part of the area. As above mentioned, a large area around the towns of Palagonia and Scordia is subject to extensive land use for the production of oranges, which implies a massive use of fertilizers and pesticides. Lastly, the distribution map of the scores of factor five (Figure 10e) shows a similar pattern as those of factors two and three, as these factors are all related, although in different fashion and intensity, to the convective ascent and spreading of geothermal/magmatic fluids and their mixing with shallower waters.

From the above results it derives a widespread occurrence of favorable conditions for exploitation of the local geothermal resource.

\subsection{Saturation Indexes}

In a solution, the values of the Saturation Index (S.I.) is defined as the logarithm of the ratio between the Ion Activity Product (I.A.P.) relative to a given mineralogical phase and the equilibrium constant of its solubility product (Ksp): S.I. $=\log$ (I.A.P./Ksp).

In Table 4 are shown the values of the S.I. for the main mineral species in the analyzed waters, calculated by the PHREEQC software [Parkhrust, 1995]. Our samples are saturated or oversaturated with respect to calcite and dolomite, as expected for groundwaters circulating into basaltic rocks alternating with carbonate formations. This suggests that both types of host rocks release bivalent cations into local groundwaters. Dissolution of the primary minerals of basalts (olivine and pyroxenes) is responsible for a progressive increase in the $\mathrm{Mg} / \mathrm{Ca}$ ratio until reaching a value close to 1 . At this point, a more severe alteration of the volcanites, accompanied by cationic exchange reactions, favors a shift of the water $\mathrm{pH}$ towards basic values and an increase of the $\mathrm{Na}$ content compared to $\mathrm{Ca}$ and Mg [Ellis and Mahon, 1977]. Under these conditions, groundwaters attain saturation with respect to carbonate minerals, thus provoking their precipitation and consequent further enrichment of the solution in monovalent ions.

Our samples are always oversaturated with respect to quartz, whereas they range from slightly undersaturated to slightly oversaturated with respect to chalcedony and they are always undersaturated with respect to fluorite, siderite, gypsum and anhydrite. Furthermore, in all our samples the values of SI for fluorite, siderite, gypsum and anhydrite show a clear negative correlation with $\mathrm{pH}$ values (Figure 11) and some samples are close to equilibrium only under marked acid and reducing conditions. 
Gloria Maria Ristuccia et al.
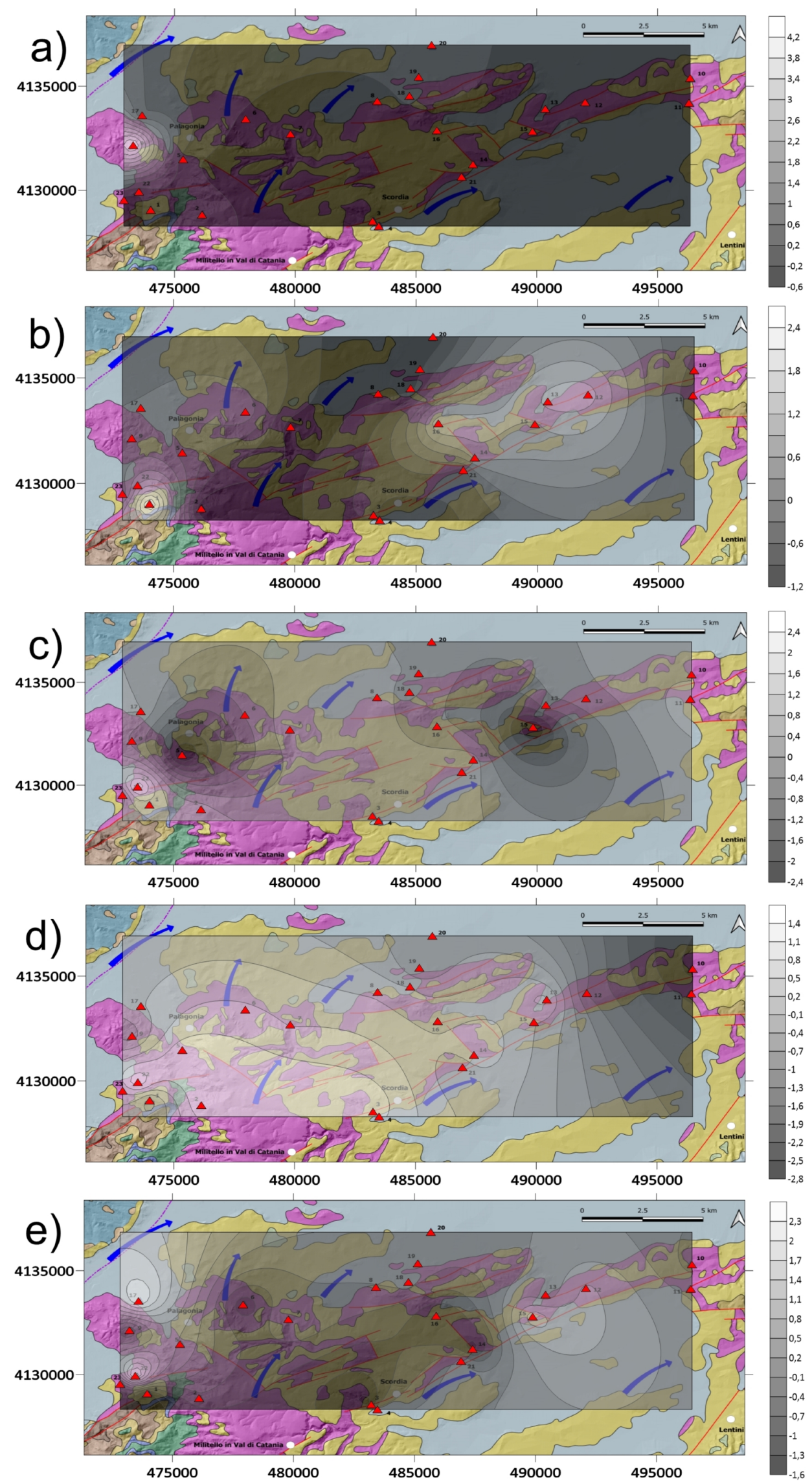

Figure 10. Distribution map of the scores of each factor obtained from PCA, after interpolation using Ordinary Kriging. The base map is the same as in Figure 2. 


\begin{tabular}{|c|c|c|c|c|c|c|c|c|}
\hline Sample & Calcite & Dolomite & Siderite & Gypsum & Anhydrite & Fluorite & Chalcedony & Quartz \\
\hline 1 & 0.988 & 2.480 & -2.536 & -1.828 & -2.041 & -2.094 & -0.191 & 0.233 \\
\hline 2 & 0.190 & 0.181 & -1.222 & -2.464 & -2.705 & -2.359 & -0.033 & 0.416 \\
\hline 3 & 0.612 & 1.532 & -5.414 & -3.104 & -3.320 & -3.614 & -0.241 & 0.185 \\
\hline 4 & 0.211 & 0.457 & -0.782 & -1.649 & -1.886 & -2.988 & 0.045 & 0.490 \\
\hline 5 & 0.100 & 0.459 & -0.618 & -1.330 & -1.470 & -0.934 & -0.094 & 0.290 \\
\hline 6 & 1.928 & 3.721 & -3.590 & -1.439 & -1.651 & -2.201 & 0.040 & 0.463 \\
\hline 7 & 0.057 & 0.028 & -1.064 & -2.248 & -2.482 & -1.920 & 0.117 & 0.558 \\
\hline 8 & 0.090 & 0.354 & -2.542 & -2.612 & -2.841 & -2.070 & 0.057 & 0.493 \\
\hline 9 & 0.565 & 1.311 & -2.268 & -1.280 & -1.488 & -0.122 & 0.316 & 0.737 \\
\hline 10 & 0.488 & 1.198 & -5.302 & -3.523 & -3.749 & -3.276 & -0.355 & 0.080 \\
\hline 11 & -0.129 & 0.403 & -3.187 & -3.343 & -3.573 & -3.643 & 0.077 & 0.515 \\
\hline 12 & 0.564 & 1.456 & -2.292 & -1.782 & -1.971 & -2.665 & 0.269 & 0.678 \\
\hline 13 & 0.871 & 1.592 & -0.953 & -0.921 & -1.102 & -1.463 & 0.202 & 0.607 \\
\hline 14 & 0.323 & 0.745 & -4.374 & -2.611 & -2.814 & -4.201 & -0.406 & 0.012 \\
\hline 15 & 0.400 & 1.009 & -0.400 & -1.318 & -1.496 & -1.385 & 0.334 & 0.737 \\
\hline 16 & 0.703 & 1.246 & - & -2.534 & -2.739 & -2.735 & -0.317 & 0.101 \\
\hline 17 & 1.032 & 2.452 & -2.636 & -1.573 & -1.777 & - & 0.582 & 1.000 \\
\hline 18 & 0.403 & 1.092 & -2.228 & -2.534 & -2.766 & -2.283 & 0.173 & 0.613 \\
\hline 19 & 0.594 & 1.562 & -2.206 & -2.177 & -2.412 & -2.234 & 0.162 & 0.606 \\
\hline 20 & 1.093 & 2.620 & -3.300 & -2.124 & -2.356 & -2.212 & 0.127 & 0.567 \\
\hline 21 & 0.509 & 1.560 & -2.388 & -1.885 & -2.109 & -2.589 & -0.039 & 0.394 \\
\hline 22 & -0.403 & -1.055 & -3.253 & -1.150 & -1.362 & -1.959 & 0.202 & 0.626 \\
\hline 23 & 0.281 & 0.890 & -2.989 & -2.396 & -2.618 & -3.310 & 0.070 & 0.502 \\
\hline
\end{tabular}

Table 4. Values of the Saturation Indexes for the main mineral species in the analyzed waters (not shown if the main element of the species was below detection limit). Computations were carried out using the software PHREEQC [Parkhrust, 1995] at the temperature and $\mathrm{pH}$ of water during sampling.

\subsection{Chemical geothermometry}

Water temperature measured at surfacing in each studied site during sampling ranged between 18 and $40^{\circ} \mathrm{C}$ (Tables 1 and 6).

In order to estimate the temperature of last equilibration of fluids at depth in the geothermal system under study we applied several different chemical geothermometers to the liquid phase, assuming: i) equilibrium between water and thermodynamically stable mineral phases in the geothermal reservoir, ii) no mixing of geothermal fluids with shallower and colder waters and iii) fast migration of ground water to the surface. Among the many geothermometers available, those better reflecting the local hydro-geochemical conditions are those based on silica, on the K/Mg ratio [Giggenbach, 1988] and on the Na/K ratio [Fournier, 1973, 1979; Truesdell, 1975; Fournier and Potter, 1979].

Furthermore, we used a graphical combination of the $\mathrm{Na} / \mathrm{K}$ and $\mathrm{K} / \mathrm{Mg}$ geothermometers proposed by Giggenbach [1988] and later modified by Giggenbach and Corrales [1992] for low-temperature natural thermal waters. The $\mathrm{Na} / \mathrm{K}$ geothermometer is less sensitive to secondary processes that may alter the pristine characteristics of reservoir water. From the data in Table 5, however, it seems that the temperature values calculated from this geothermometer are exceedingly high, most likely because at low temperature the $\mathrm{Na} / \mathrm{K}$ ratio in water is governed by rock leaching rather than by chemical equilibrium [Mutlu and Güleç, 1998], mainly when this geothermometer is applied to waters with high calcium contents [Fournier e Truesdell, 1973]. 


\section{Gloria Maria Ristuccia et al.}

The K/Mg geothermometer [Giggenbach, 1988] provides temperature values markedly lower than those obtained from quartz geothermometers (Table 5). In two cases (samples 14 and 16) the calculated temperature values are even lower than those at surface emergency. This is probably due to leaching of $\mathrm{Mg}$ from host rocks during water motion towards the surface, which makes Mg concentrations in solution higher than expected at the reservoir thermal conditions. This in turn causes underestimation of deep-water temperature, given that the equation used for this geothermometer is based on the $\mathrm{K} / \sqrt{\mathrm{Mg}}$ ratio [Mutlu and Güleç, 1998]. For these reasons, in our case the $\mathrm{K} / \mathrm{Mg}$ geothermometer seems to eventually reflect rather shallow equilibrium conditions, therefore it is not a reliable indicator of deep temperature.

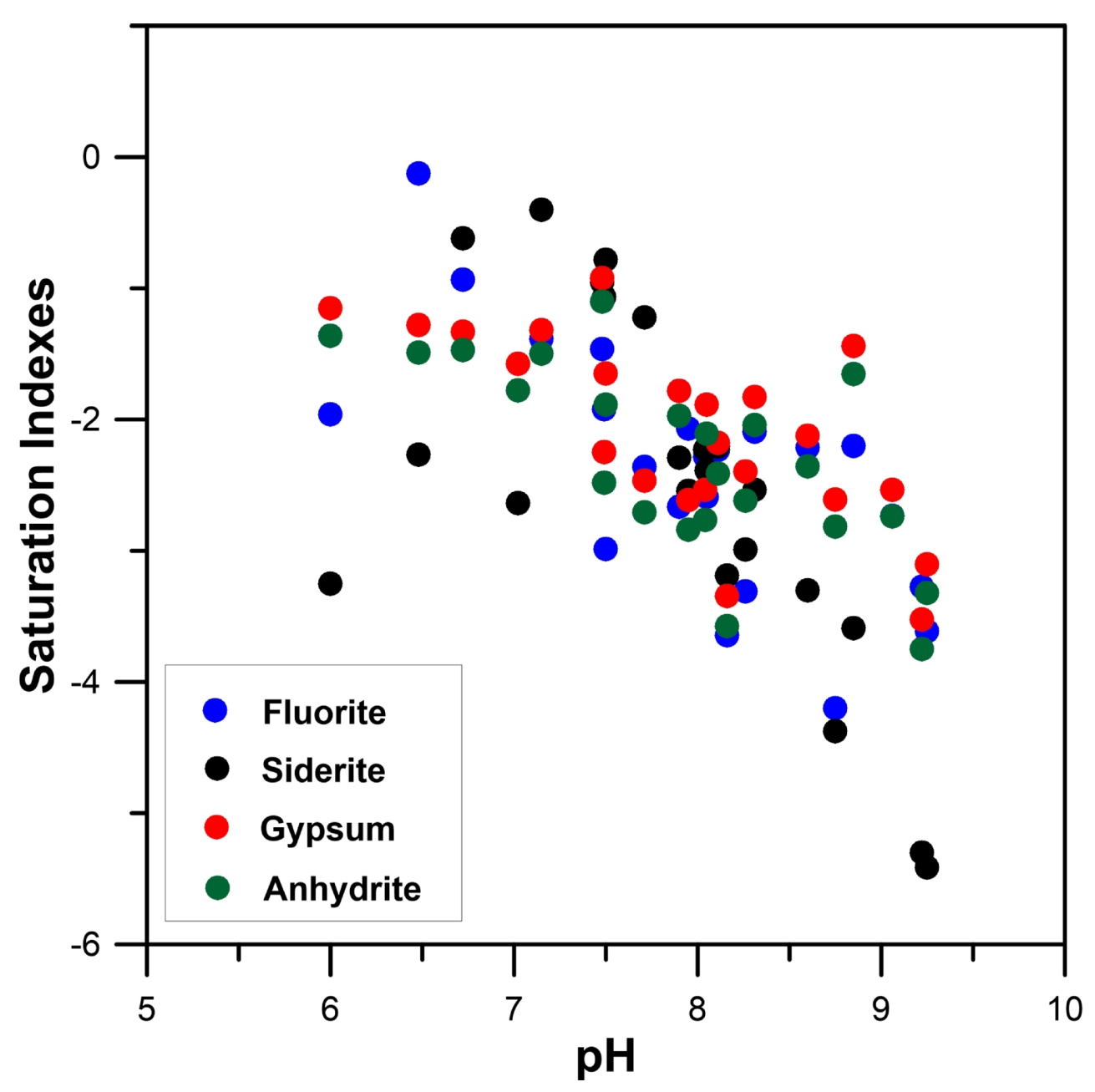

Figure 11. Correlation plots of pH values vs. SI values of (a) fluorite, (b) siderite, (c) gypsum and (d) anhydrite in the sampled waters.

Other geothermometers widely used in geothermal exploration are those based on silica concentrations in water, as the minerals of element increase their solubility with increasing water temperature [Fournier, 1973, 1991]. However, under highly diluted conditions, such as those of our water samples, most of these geothermometers are not entirely reliable. Actually, data in Table 5 show that the results obtained from use of amorphous silica, christobalite $\alpha$ and $\beta$ and chalcedony geothermometers (Table 5) gave calculated temperature values exceedingly low (in many cases even negative). Only the geothermometers based both on quartz with no steam loss and on quartz considering maximum steam loss [Fournier, 1973, 1991] gave reliable values, more or less intermediate between those from the many $\mathrm{Na} / \mathrm{K}$ geothermometers and those from the $\mathrm{K} / \mathrm{Mg}$ one. 
Geothermal systems in east Sicily

\begin{tabular}{|c|c|c|c|c|c|c|c|c|}
\hline Sample & $\mathbf{T}_{\mathbf{W}}$ & $\mathrm{SiO}_{2} \mathbf{Q z}$ & $\mathrm{SiO}_{2} \mathrm{Qz} \mathrm{SL}$ & $\mathrm{K} / \mathrm{Mg}(1)$ & $\mathrm{Na} / \mathrm{K}(2)$ & $\mathrm{Na} / \mathrm{K}$ (3) & $\mathrm{Na} / \mathrm{K}(4)$ & $\mathrm{Na} / \mathrm{K}(5)$ \\
\hline 1 & 26.6 & 44 & 52 & 50 & 52 & 63 & 120 & 111 \\
\hline 2 & 18.6 & 48 & 56 & 58 & 248 & 247 & 289 & 262 \\
\hline 3 & 26.0 & 48 & 55 & 38 & 131 & 138 & 193 & 177 \\
\hline 4 & 19.8 & 56 & 62 & 58 & 234 & 233 & 277 & 252 \\
\hline 5 & 40.1 & 63 & 69 & 53 & 153 & 159 & 212 & 194 \\
\hline 6 & 27.0 & 67 & 72 & 53 & 91 & 101 & 157 & 144 \\
\hline 7 & 21.1 & 63 & 69 & 59 & 199 & 201 & 250 & 228 \\
\hline 8 & 22.8 & 60 & 66 & 51 & 153 & 159 & 212 & 194 \\
\hline 9 & 27.4 & 87 & 90 & 72 & 119 & 127 & 182 & 167 \\
\hline 10 & 23.3 & 36 & 44 & 30 & 83 & 93 & 149 & 137 \\
\hline 11 & 22.2 & 62 & 67 & 44 & 146 & 153 & 206 & 189 \\
\hline 12 & 31.7 & 89 & 91 & 37 & 134 & 141 & 195 & 179 \\
\hline 13 & 33.1 & 83 & 87 & 44 & 148 & 154 & 207 & 190 \\
\hline 14 & 28.8 & 32 & 41 & 24 & 87 & 97 & 153 & 141 \\
\hline 15 & 33.7 & 97 & 98 & 43 & 143 & 150 & 203 & 186 \\
\hline 16 & 28.4 & 42 & 49 & 16 & 90 & 100 & 156 & 143 \\
\hline 17 & 28.5 & 118 & 116 & 71 & 107 & 116 & 171 & 157 \\
\hline 18 & 21.5 & 69 & 74 & 55 & 144 & 151 & 204 & 187 \\
\hline 19 & 20.5 & 67 & 72 & 62 & 74 & 84 & 141 & 129 \\
\hline 20 & 21.6 & 67 & 72 & 60 & 121 & 129 & 184 & 169 \\
\hline 21 & 23.9 & 53 & 60 & 54 & 106 & 115 & 170 & 156 \\
\hline 22 & 26.5 & 76 & 80 & 47 & 115 & 123 & 179 & 164 \\
\hline 23 & 24.2 & 63 & 69 & 40 & 70 & 81 & 138 & 127 \\
\hline
\end{tabular}

(1) from Giggenbach [1988]; (2) from Fournier [1973]; (3) from Truesdell [1975]; (4) from Fournier and Potter [1979];

(5) from Fournier [1979].

Table 5. Geothermometer temperature $(\mathrm{Qz}=$ quartz; $\mathrm{SL}=$ Steam Loss $)$ and measured water temperature $\left(\mathrm{T}_{\mathrm{W}}\right)$ of sampled waters. All values in ${ }^{\circ} \mathrm{C}$.

In order to get the best and most useful information from the above geothermometers, we used a graphical technique obtained combining the two chemical geothermometers that respond most quickly and with comparable speed to changes in water temperature, that is, those based on total dissolved silica and on the $\mathrm{K}^{2} / \mathrm{Mg}$ ratio in solution [Giggenbach et al., 1994]. In Figure 12, equilibrium silica concentrations (in $\mathrm{mg} / \mathrm{kg}$ ) are calculated by means of the following equation [Giggenbach et al., 1994]:

$$
\log \left(\mathrm{SiO}_{2}\right)=4.55-(1000 / \mathrm{T}+273.15)
$$

Equilibrium $\mathrm{K}^{2} / \mathrm{Mg}$ ratios are computed by means of equation:

$$
\mathrm{T}_{\mathrm{KMg}}\left({ }^{\circ} \mathrm{C}\right)=\left[\left(4410 /\left(14.0+\log \left(\mathrm{K}^{2} / \mathrm{Mg}\right)\right)\right]-273.15\right.
$$

These two equations apply if we assume that groundwaters cool down conductively, that is to say without steam loss or chemical re-equilibration at decreasing temperatures. The corresponding full-equilibrium line is labelled "conductive cooling" in Figure 12. The increase in the concentrations of the above solutes caused by maximum steam separation at equilibrium temperature down to $100^{\circ} \mathrm{C}$ (or maximum adiabatic cooling) can be calculated using the following equations [Giggenbach et al., 1994]: 
Gloria Maria Ristuccia et al.

$$
\begin{gathered}
\log \left(\mathrm{SiO}_{2}\right)=5.12-[1215 /(\mathrm{T}+273.15)] \\
\log \left(\mathrm{K}^{2} / \mathrm{Mg}\right)=14.6-[4630 /(\mathrm{T}+273.15)]
\end{gathered}
$$

The corresponding full-equilibrium line is marked "adiabatic cooling” in Figure 12. Most of our samples plot close to the full-equilibrium lines with a maximum estimated equilibrium temperature of about $80^{\circ} \mathrm{C}$. However, some important deviations are observed: in the case of samples 1, 3, 10,14 and 16 this is possibly due to loss of silica, which shifts data points downwards, as well as to loss of $\mathrm{Mg}$, which shifts data points to the right. Both elements may have been lost from our samples during the interval between sampling and laboratory analysis. It is therefore difficult to identify the prevailing reason of disequilibrium given the lack of additional information. Samples 9 and 17 plot in-between the full equilibrium line and the amorphous silica (the most soluble silica polymorph) line, probably because their silica contents are controlled by saturation with a silica polymorph of intermediate solubility. Amorphous silica solubility line represents the ultimate saturation limit for silica, but this is normally valid for waters with acidity higher than that of our samples.

From the above discussion it is clear that all of the studied waters, even those with the highest measured or calculated temperature, are far from having reached equilibrium with the host rocks in the geothermal reservoir(s). Their composition is, therefore, mainly a result of iso-chemical rock dissolution favored by the high acidity of water due to input of deep $\mathrm{CO}_{2}$ and by relatively low reaction temperature.

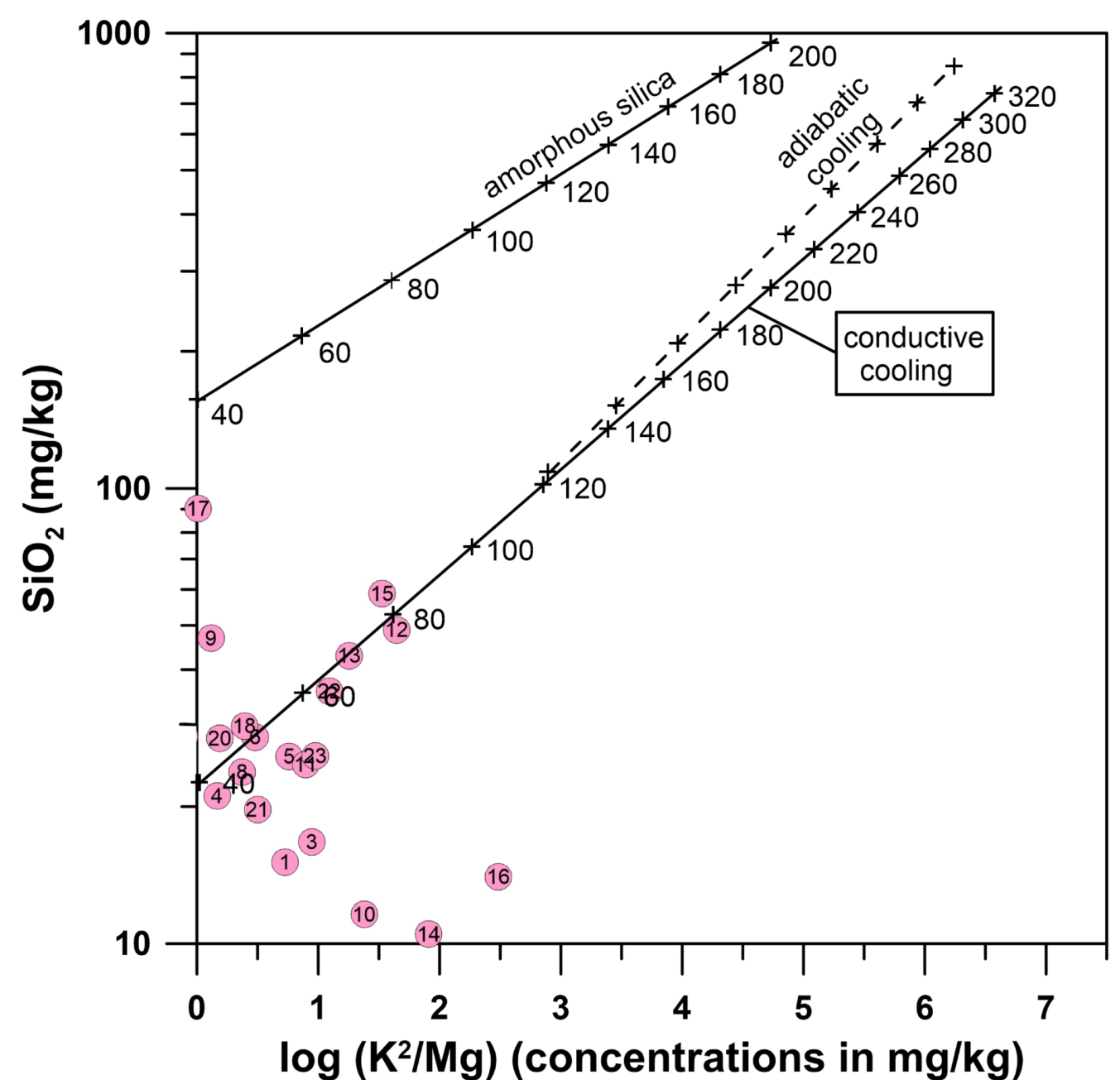

Figure 12. Plot of $\log \left(\mathrm{K}^{2} / \mathrm{Mg}\right)$ vs. $\log \left(\mathrm{SiO}_{2}\right)$ (from Giggenbach et al., 1994, modified). Numbers on the lines of amorphous silica, conductive cooling and adiabatic cooling show temperature values in ${ }^{\circ} \mathrm{C}$. 
Despite this, possible reservoir temperature estimates were modeled also using the Saturation Index method of Reed and Spycher [1984], calculated only in some samples (i.e., samples 1, 5, 9, 12, 13, 14, 15, 16 and 18) selected among those with the highest scores of factors two (i.e., that describing a contribution from geothermal fluids) calculated from PCA. According to this method, the temperature range at which most of the minerals are at equilibrium $(\log$ S.I. $=0$ ) is considered as that representing minimum temperature conditions at depth. The SI was calculated for all possible mineral assemblages given the sample composition and at temperature ranging from $20^{\circ}$ $\mathrm{C}$ to $200^{\circ} \mathrm{C}$, in steps of $10^{\circ} \mathrm{C}$. The results (Figure 13) show that the minerals ruling the studied waters are primarily chalcedony, quartz, calcite and aragonite and, secondarily and with a much lesser frequency, also dolomite, chrysotile and anhydrite, in decreasing order of importance. A large uncertainty was found in the results for many of the selected samples, mostly due to unrealistic SI values obtained when using most of the mineral assemblages. This is likely due to constant oversaturation conditions of carbonate phases (e.g., samples 9, 15 and 18) and/or to progressive undersaturation of silica minerals due to silica loss (in particular for sample 16). Considering the range of temperature around the saturation interval (S.I. $=0 \pm 0.5$ ), we obtained equilibrium temperatures ranging from about $40^{\circ} \mathrm{C}$ to about $105^{\circ} \mathrm{C}$. Comparison between these results and those obtained from the $\operatorname{logSiO} \mathrm{vs}_{2} \mathrm{k}^{2} / \mathrm{Mg}$ plot of Figure 12 indicates a general agreement between the two methods (Table 6). The largest discrepancies (either positive or negative) were found in those samples (i.e., 12, 13, 15 and 16) that in the $\operatorname{logSiO} \mathrm{V}_{2} \mathrm{vs} . \mathrm{k}^{2} / \mathrm{Mg}$ plot showed the highest calculated temperature values.

\begin{tabular}{ccc} 
Sample & $\mathrm{T}^{\circ}$ (S.I. method) & $\mathrm{T}^{\circ} \mathbf{( l o g S i O}_{2}$ vs. $\left.\mathbf{K}^{2} \mathbf{M g}\right)$ \\
\hline 1 & $48-67$ & 55 \\
\hline 5 & $67-86$ & $52-58$ \\
\hline 9 & $20-48$ & 40 \\
\hline 12 & $29-58$ & $79-81$ \\
\hline 13 & $105-114$ & 70 \\
\hline 14 & $77-124$ & $50-88$ \\
\hline 15 & $39-67$ & 78 \\
\hline 16 & $133-162$ & $63-105$ \\
\hline 18 & $29-48$ & 49 \\
\hline
\end{tabular}

Table 6. Confrontation between reservoir temperatures estimated using the Saturation Indexes method [Reed and Spycher, 1984] and those using the $\operatorname{logSiO}{ }_{2}$ vs. $\mathrm{k}^{2} / \mathrm{Mg}$ plot of Figure 12, only for the samples belonging to factor 2 of PCA. Temperature values (expressed in ${ }^{\circ} \mathrm{C}$ ) often show a wide range, depending on the chemical and physical processes affecting water (silica depletion, carbonate minerals oversaturation and precipitation, etc.).

\section{Conclusions}

Our study of the slight thermal groundwaters $\left(\mathrm{T}<40^{\circ} \mathrm{C}\right)$ in the Scordia-Lentini graben proved a useful test for the geochemical characterization of the area, aimed at defining and assessing both the geothermal conditions at depth and the crustal pathways for the migration of geothermal fluids.

Our interpretation of data suggests that rain water infiltrates in the ground forming large groundwater reservoirs (Figure 14). Groundwaters in part interact with local host rocks (carbonate rocks and/or basaltic lavas) causing leaching of minerals favored by a large input of deep $\mathrm{CO}_{2}$, but in part they mix with geothermal fluids that come from depth and migrate towards the surface moving along the many tectonic structures that cross the area. Geothermal fluids most probably originate from magmatic/mantle fluids that condensate as brines along their way to the surface and form small reservoirs at temperature in the range from about 100 to about $120^{\circ} \mathrm{C}$. 
Gloria Maria Ristuccia et al.
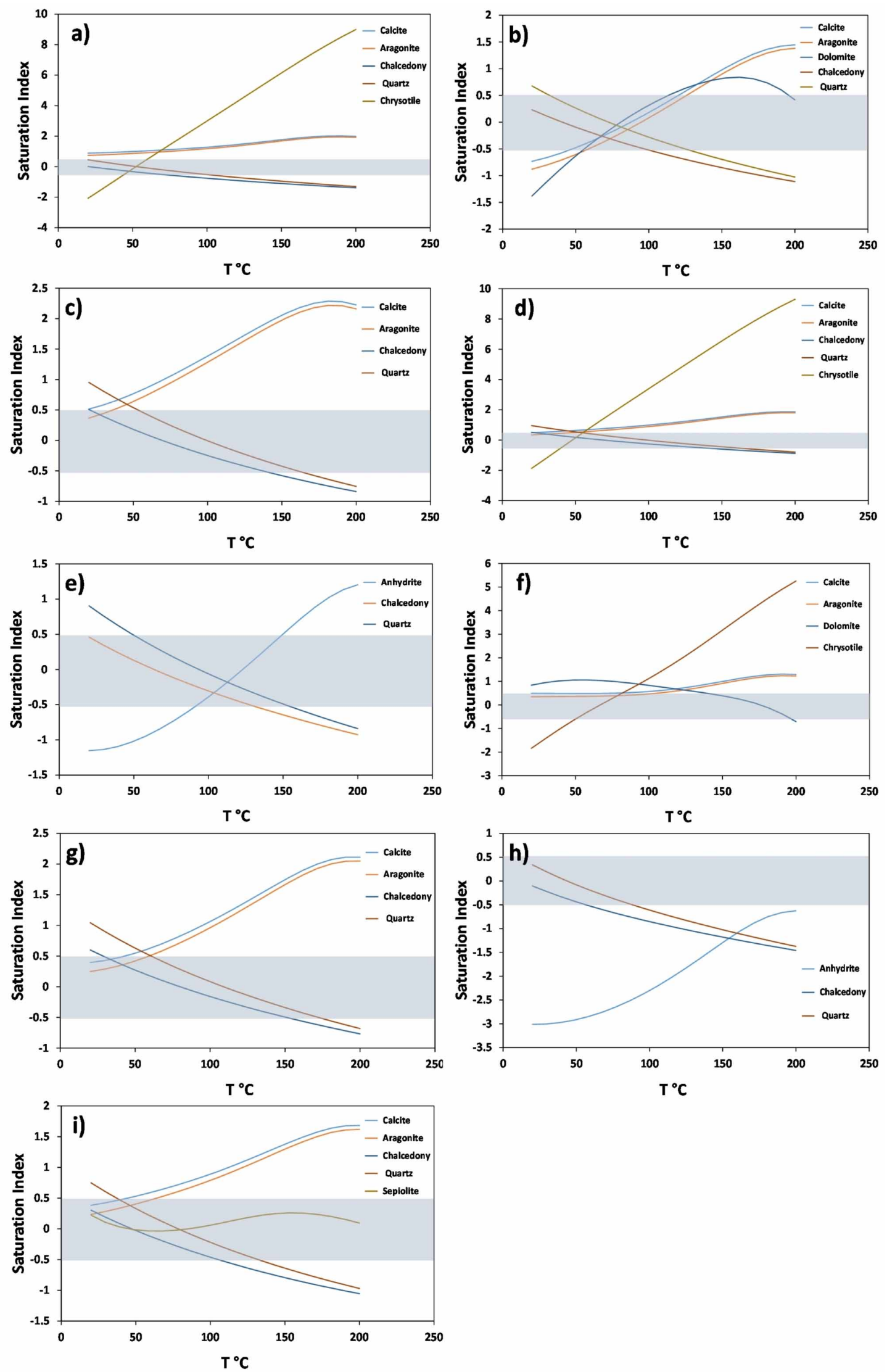

Figure 13. Saturation indexes of mineral phases vs. equilibrium temperature for samples 1 (plot a), 5 (plot b), 9 (plot c), 12 (plot d), 13 (plot e), 14 (plot f), 15 (plot g), 16 (plot h) and 18 (plot i). Grey horizontal bands indicate the saturation intervals (S.I. $=0 \pm 0.5)$. 


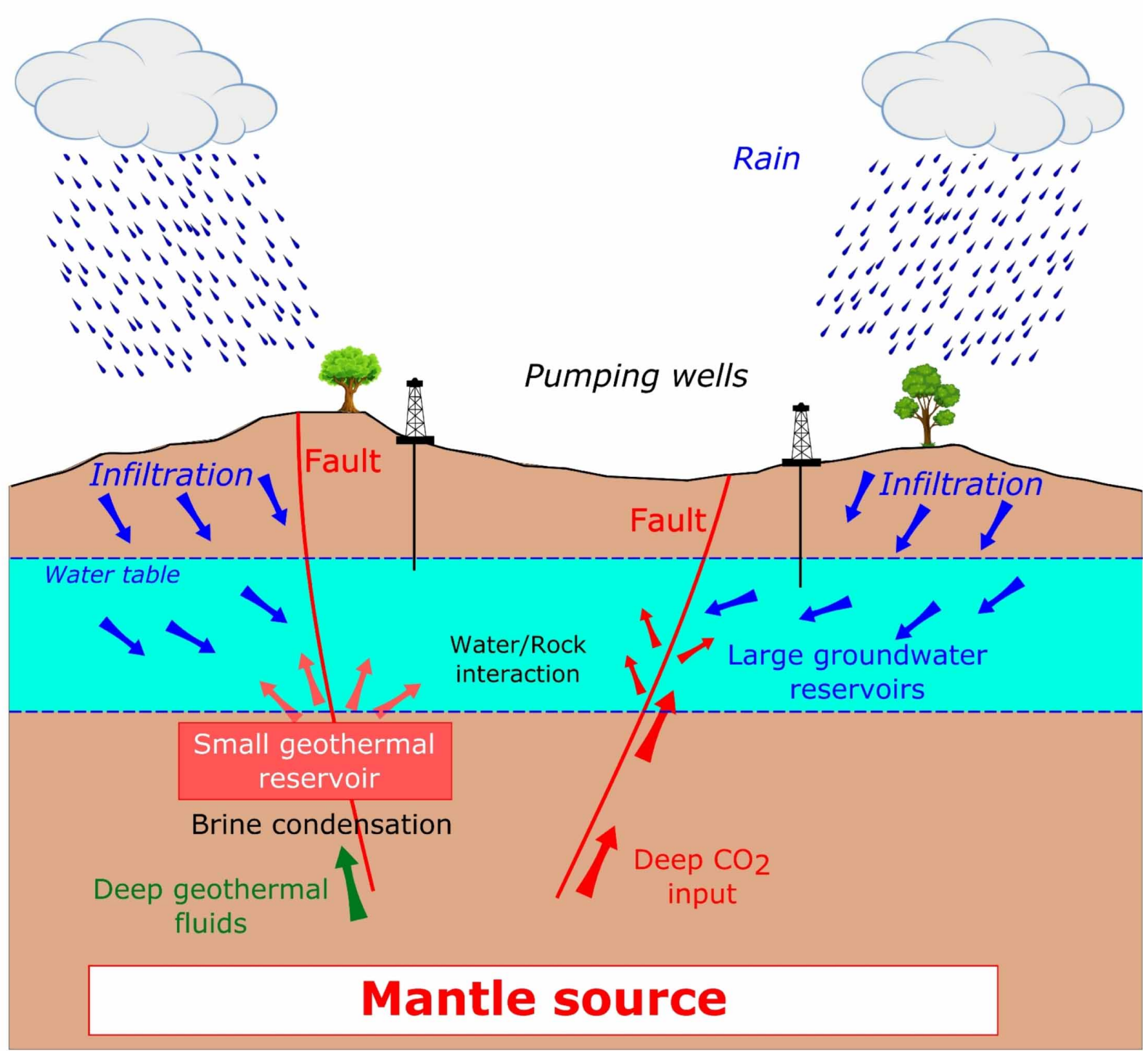

Figure 14. Conceptual model of fluids circulation in the study area, highlighting the pathways of migration of deep fluids (both geothermal and $\mathrm{CO}_{2}$-rich magmatic fluids) towards the surface, the condensation of geothermal fluids to form brines in small geothermal reservoirs and the interactions between deep fluids and shallow groundwater.

The high geothermal gradient in the study area is controlled by extensive tectonics connected with the large plumbing system of Mt. Etna [Caracausi et al., 2003a]. As described by Cataldi et al., [1995] and Barbier et al., [1988], under such conditions anomalous high heat fluxes originate from circulation and condensation of high-enthalpy fluids produced from a deep mantle source, whose upper boundary upwells due to tectonic-induced drop of lithostatic pressure.

However, both the chemical characteristics of waters and the carbon isotopes composition of TDIC do not rule out a contribution from purely tectonic thermal fluids ("sedimentary" brines), that are commonly found in active tectonic areas and form from strong friction along faults. In both cases, the above considerations lead to the hypothesis of an almost infinite geothermal source, at least in terms of duration in human time-scales. Mapping the distribution of factors loadings calculated from PCA indicated that "geothermal" groundwaters are present in most of the study area, thus making the area potentially exploitable for the use of the local geothermal resource. 


\section{Gloria Maria Ristuccia et al.}

Furthermore, the average depth of the wells with the highest water temperature suggests that local geothermal reservoirs are relatively shallow (probably slightly deeper than $500 \mathrm{~m}$ below the surface), which would allow for a cost-effective exploration and exploitation of the geothermal resource.

Acknowledgements. This work was part of the master thesis of G. Castorina and it was carried out within the framework of the Geothermal Atlas of Southern Italy Project. We thank two anonymous reviewers and the Associate Editor for their useful comments and suggestions.

\section{References}

Adam, J., C.D. Reuther, M. Grasso and L. Torelli (2000). Active fault kinematics and crustal stresses along the Ionian margin of southeastern Sicily, Tectonophysics, 326, 3-4, 217-239, https://doi.org/10.1016/S00401951(00)00141-4

Agip (1978). Carta gravimetrica della Sicilia: anomalie di Bouger, Sevizio geologico d'Italia, Agip, Scala 1:500.000

Aiuppa, A., P. Allard, W. D’Alessandro, A. Michel, F. Parello, M. Treuil, and M. Valenza (2000a). Mobility and fluxes of major, minor and trace metals during basalt weathering and groundwater transport at Mt. Etna volcano (Sicily), Geochimica et Cosmochimica Acta, 64 (11), 1827-1841, https://doi.org/10.1016/S0016-7037(00)00345-8

Aiuppa, A., G. Dongarrà, G. Capasso and P. Allard (2000b). Trace elements in the thermal groundwaters of Vulcano Island (Sicily), J. Volcanol. Geotherm. Res., 98, 1-4, 189-207, https://doi.org/10.1016/S0377-0273(99)00156-0

Alaimo, R., M. Carapezza, G. Dongarrà and S. Hauser (1978). Geochimica delle sorgenti termali siciliane, Soc. Ital. Mineral. Petrol., 34, 2, 577-590.

Allard, P. (1986). Geochimique isotopique et origine de l'eau, du carbone et du sufre dans le gaz volcanique: zones de rift, marges continentales et arcs insulaires, Thesis, Univ. Paris

Appelo, C.A.J. and Postma, D. (1993). Geochemistry, Groundwater and Pollution. Balkema, Rotterdam, 536, https://doi.org/10.1017/S0016756800011523.

Aureli, A., G. Adorni, F. Fazio, G. Pistorio, A. Privitera, R. Ruggieri, G. Silluzio (1997). Carta della vulnerabilità delle falde idriche. Settore nord-occidentale ibleo (Sicilia SE). CNR-GNDCI.

Aureli, A., G. Adorni, A.F. Chiavetta, F. Fazio, S. Fazzina and G. Messineo (1989). Carta della vulnerabilità delle falde idriche. Settore nord orientale Ibleo (Sicilia SE). CNR-GNDCI.

Azzaro, R. and M.S. Barbano (2000). Analysis of the seismicity of Southeastern Sicily: a proposed tectonic interpretation, Ann. Geophys., 43, 1, 171-188.

Barberi, F., L. Civetta, P. Gasparini, F. Innocenti, R. Scandone and L. Villari (1974). Evolution of a Section of AfricaEurope Plate Boundary - Paleomagnetic and Volcanological Evidence from Sicily, Earth Planet. Sci. Lett., 22, 2, 123-132, https://doi.org/10.1016/0012-821x(74)90072-7.

Barberi, F., P. Gasparini, F. Innocenti and L. Villari (1973). Volcanism of the southern Tyrrhenian Sea and its geodynamic implications, J. Geophys. Res., 78, 23, 5221-5232, https://doi.org/10.1029/JB078i023p05221

Barbier, E., F. Musmeci and P. Saracco (1988). Banca Nazionale dei dati Geotermici - Istituto internazionale Ricerche Geotermiche, CNR Internal Report.

Battaglia, M., A. Cimino, G. Dongarrà, V. Gottini, S. Hauser and S. Rizzo S. (1991). Hydrogeological and chemical outlines of the margin area Palagonia-Lentini-Augusta (South-Eastern Sicily), Mem. Soc. Geol. It., 46, 567 - 573.

Behncke, B. (2004). Late Pliocene volcanic island growth and flood basalt-like lava emplacement in the Hyblean Mountains (SE Sicily), J. Geophys. Res., 109, https://doi.org/10.1029/2003JB002937.

Beneo, E. (1960). La ricerca petrolifera in Italia meridionale, Boll. Serv. Geol. It., 80, 1-12.

Bianchi, F., S. Carbone, M. Grasso, G. Invernizzi, F. Lentini, G. Longaretti, S. Merlini and F. Mostardini (1987). Sicilia orientale: profilo geologico Nebrodi-Iblei, Mem. Soc. Geol. It., 38, 429-458

Boccaletti, M. and P. Manetti (1978). The Tyrrhenian Sea and Adjoining Regions. In: Nairn A.E.M., Kanes W.H., Stehli F.G. (eds), The Ocean Basins and Margins, Springer, Boston, MA.

Bonfanti, P., M.L. Carapezza, W. D’Alessandro, R. De Domenico, I.S. Diliberto, R. Di Liberto, S. Giammanco, S. Gurrieri, F. Parello and M. Valenza (1993). Earthquake of December 13, 1990, in eastern Sicily: some geochemical investigations, In Scientific meeting on the seismic protection, Venice, 12-13 July, 1993,176-184. 
Bonforte, A., S. Catalano, R. Maniscalco, G. Romagnoli, G. Sturiale and G. Tortorici (2012). Active deformation along the northern margin of the Hyblean Plateau (SE Sicily) from GPS and geological data, Rend. Online Soc. Geol. It., 21, 317-319

Bousquet, J.C. and G. Lanzafame (2004). The tectonics and geodynamics of Mt. Etna: synthesis and interpretation of geological and geophysical data. In: Bonaccorso, A., Calvari, S., Coltelli, M., Del Negro, C., Falsaperla, S. (Eds.), Mt. Etna: Volcano Laboratory: American Geophysical Union, Geophysical Monograph, 143, 29-47, https://doi.org/10.1029/GM143.

Bousquet, J.C., G. Lanzafame and C. Paquin (1988). Tectonic stresses and volcanism: in situ stress measurements and neotectonic investigations in the Etna area (Italy), Tectonophysics, 149, 219-31, https://doi.org/10.1016/00401951(88)90174-6.

CNR-PFE (1982). Manifestazioni idrotermali italiane: appendice al volume RF 13. Contributo alla conoscenza delle risorse geotermiche del territorio italiano, Roma, dicembre 1982.

Capasso, G., W. D’Alessandro, R. Favara, S. Inguaggiato and F. Parello (2001). Interaction between the deep fluids and the shallow groundwaters on Vulcano island (Italy), J. Volcanol. Geotherm. Res., 108, 1-4, 187-198. https://doi.org/10.1016/S0377-0273(00)00285-7.

Capasso, G., G. Dongarrà, R. Favara, S. Hauser and M. Valenza (1992). Isotope composition of rain water, well water and fumarole steam on the island of Vulcano, and their implications for volcanic surveillance, J. Volcanol. Geotherm. Res., 49, 1-2, 147-155. https://doi.org/10.1016/0377-0273(92)90010-B.

Capasso, G. and S. Inguaggiato (1998). A simple method for the determination of dissolved gases in natural waters. An application to thermal waters from Vulcano Island, Appl. Geochem., 13, 5, 631-642, https://doi.org/10.1016/S0883-2927(97)00109-1.

Caracausi, A., M. Ditta, F. Italiano, M. Longo, R. Maugeri, P.M. Nuccio and A. Paonita (2004). Inferences on physicochemical conditions and gas-water interaction by new quantitative approaches: The case of Panarea (Italy), Geochimica et Cosmochimica Acta, 68, 11, Supplement 264.

Caracausi, A., R. Favara, S. Giammanco, P.M. Nuccio, A. Paonita, G. Pecoraino and A. Rizzo (2003a). Mount Etna: Geochemical signals of magma ascent and unusually extensive plumbing system, Geophys. Res. Lett., 30, 2 , 1057, https://doi.org/10.1029/2002GL015463.

Caracausi, A., F. Italiano, A. Paonita and A. Rizzo (2003b). Evidence of deep magma degassing and ascent by geochemistry of peripheral gas emissions at Mount Etna (Italy): Assessment of the magmatic reservoir pressure, J. Geophys. Res., 108, B10, 2463, https://doi.org/10.1029/2002JB002095.

Carbone, S., M. Grasso and F. Lentini (1982). Considerazioni sull'evoluzione geodinamica della Sicilia sud-orientale dal Cretaceo al Quaternario, Mem. Soc. Geol. It., 24, 367-386

Carbone, S., M. Grasso and F. Lentini (1987). Lineamenti geologici del Plateau Ibleo (Sicilia SE). Presentazione delle carte geologiche della Sicilia sud-orientale, Mem. Soc. Geol. It., 38, 127-135.

Catalano, S., G. De Guidi, G. Lanzafame, C. Monaco, S. Torrisi, G. Tortorici and L. Tortorici (2006). Inversione tettonica positiva tardo-quaternaria nel Plateau Ibleo (Sicilia SE), Rend. Soc. Geol. It., 2, Nuova Serie, 118-120.

Catalano, S., G. De Guidi, G. Romagnoli, S. Torrisi, G. Tortorici and L. Tortorici (2008). The migration of plate boundaries in SE Sicily: influence on the large-scale kinematic model of the African promontory in southern Italy, Tectonophysics, 449, 41-62, https://doi.org/10.1016/j.tecto.2007.12.003.

Catalano, S., G. Romagnoli and G. Tortorici (2010). Kinematics and dynamics of the late quaternary rift-flank deformation in the Hyblean Plateau (SE Sicily), Tectonophysics, 486, 1-14. https://doi.org/10.1016/j.tecto.2010.01.013.

Catalano, S., S. Torrisi and C. Ferlito (2004). The relationship between Late Quaternary deformation and volcanism of Mt. Etna (eastern Sicily): new evidence from the sedimentary substratum in the Catania region, J. Volcanol. Geotherm. Res., 132, 311-334, https://doi.org/10.1016/S0377-0273(03)00433-5.

Cataldi, R., F. Mongelli, P. Squarci, L. Taffi, G. Zito and C. Calore (1995). Geothermal ranking of italian territory, Geothermics, 24, 1, 115-129, https://doi.org/10.1016/0375-6505(94)00026-9.

Chiodini, G., W. D’Alessandro and F. Parello (1996). Geochemistry of gases and waters discharged by the mud volcanoes at Paternò, Mt. Etna (Italy), Bull Volcanol., 58, 51-58. https://doi.org/10.1007/s004450050125.

Craig, H. (1961). Isotopic variation in meteoric waters, Science 133, 1702-1703, https://doi.org/10.1126/science.133.3465.1702.

Craig, H. (1963). The isotopic geochemistry of water and carbon in geothermal areas. In: Nuclear Geology in 


\section{Gloria Maria Ristuccia et al.}

Geothermal Areas. Tongiorgi Ed. CNR, 17.

D’Amore, F. and C. Panichi (1985). Geochemistry in geothermal exploration, Int. J. Energy Res., 9, 3, 277-298, https://doi.org/10.1002/er.4440090307.

Dall'Aglio, M., F. Quattrocchi and S. Tersigni (1995). Geochemical evolution of groundwater of the Iblean Foreland (Southeastern Sicily) after the December 13, 1990, earthquake (M = 5.4), Ann. Geophys., 38, 2, 309-329, https://doi.org/10.4401/ag-4126.

De Gregorio, S., I.S. Diliberto, S. Giammanco, S. Gurrieri and M. Valenza (2002). Tectonic control over large-scale diffuse degassing in eastern Sicily (Italy), Geofluids, 2, 273-284, https://doi.org/10.1046/j.14688123.2002.00043.x.

Della Vedova, B., Bellani, S., Pellis, G., Squarci, P. (2001). Deep temperatures and surface heat flow distribution. In: Vai, G.B., Martini, I.P. (Eds.), Anatomy of an Orogen, The Apennines and Adjacent Mediterranean Basins, Kluwer Ac. Publ., UK, 65-76.

Di Geronimo, I., F. Ghisetti, F. Lentini and L. Mezzani (1978). Lineamenti neotettonici della Sicilia orientale, Mem. Soc. Geol. It., 19, 543-549.

Doglioni, C., E. Gueguen, P. Harabaglia and F. Mongelli (1999). On the origin of W-directed subduction zones and applications to the western Mediterranean. In: Durand, B., Jolivet, L., Horvàth, F., Séranne, M. (eds.). The Mediterranean Basins: tertiary Extension within the Alpine Orogen, London, Geol. Soc., Special Pub., 156, 541-561.

Dongarrà, G. and S. Hauser (1982). Isotopic composition of dissolved sulphate and hydrogen sulphide from some thermal springs of Sicily, Geothermics, 11, 3, 193-200. https://doi.org/10.1016/0375-6505(82)90027-X.

Ellis, A. J. and W.A.J. Mahon (1977). Chemistry and geothermal systems, Academic Press, New York, 392.

ENEL, ENI-AGIP, CNR, ENEA (1988). Inventario delle Risorse Geotermiche Nazionali - Indagine D’insieme Sul Territorio Nazionale. Ministero dell'Industria, del Commercio e dell'Artigianato (currently Ministero dello Sviluppo Economico), 75.

Epstein, S. and T. Mayeda (1953). Variation of ${ }^{18} \mathrm{O}$ content of water from natural sources, Geochimimica et Cosmochimica Acta, 4, 213-224.

Favara, R., F. Grassa and S. Inguaggiato (1999). Chemical and isotopic features of dissolved gases from thermal springs of Sicily, Italy. In: Armannson, H. (Ed.), Proceedings of The Fifth International Symposium on the Geochemistry of the Earth's Surface, Balkema, Rotterdam, 495-498.

Favara, R., F. Grassa, S. Inguaggiato and F. D’Amore (1998). Geochemical and hydrogeological characterization of thermal springs in Western Sicily, Italy, J. Volcanol. Geotherm. Res., 84, 125-141, https://doi.org/10.1016/S03770273(98)00035-3.

Favara, R., F. Grassa, S. Inguaggiato and M. Valenza (2001a). Hydrogeochemistry and stable isotopes of thermal springs: earthquake-related chemical changes along Belice Fault (Western Sicily), Appl. Geochem., 16, 1-17.

Favara, R., F. Grassa and M. Valenza (2001b). Climate and isotope features of precipitation in a semi-arid area (Southeastern Sicily) and relationship with local groundwaters, IAEA-CN-80/P-18, 138-140.

Fournier, R.O. (1973). Silica in thermal waters: laboratory and field investigations, Proc. Int. 1 Symp. Hydrogeochem. Biogeochem., Tokyo, 122-139.

Fournier, R.O. (1979). A revised equation for the Na-K geothermometers, Geothermal Res. Council Trans., 5, 1-16.

Fournier, R.O. (1991) Water geothermometers applied to geothermal energy, In Application of Geochemistry in Geothermal Reservoir Development, (F. D’Amore, coordinator), UNITAR, 37-69.

Fournier, R.O. and R.W. Potter (1979). Magnesium correction to the Na-K-Ca chemical geothermometers, Geochimica et Cosmochimica Acta, 43, 1543-1550, https://doi.org/10.1016/0016-7037(79)90147-9.

Fournier, R.O. and A.H. Truesdell (1973). An Empirical Na-K-Ca Geothermometer for Natural Waters, Geochimica et Cosmochimica Acta, 37, 5, 1255-1275, https://doi.org/10.1016/0016-7037(73)90060-4.

Gat, J.R. and I. Carmi (1970). Evolution of the isotopic composition of atmospheric waters in the Mediterranean Sea area, J. Geophys. Res., 75, 3039-3048, https://doi.org/10.1029//C075i015p03039.

Ghisetti, F. and L. Vezzani (1980). The structural features of the Hyblean Plateau and the Mount Judica area (SouthEastern Sicily): a microtectonic contribution to the deformational history of the Calabrian arc, Boll. Soc. Geol. It., 99, 55-102.

Giammanco S., D. Cinti, D. Condarelli, G. Di Stefano, G. Galli, V. Longo, F. Quattrocchi, A. Sciarra and N. Voltattorni (2018). Discrete monitoring of chemical parameters in ground waters of Mt. Etna volcano: 2000-2006, J. 


\section{Geothermal systems in east Sicily}

Volcanol. Geotherm. Res., 358, 273-287, https://doi.org/10.1016/j.jvolgeores.2018.06.001.

Giammanco, S., S. Inguaggiato and M. Valenza (1998a). Soil and fumarole gases of Mount Etna: Geochemistry and relations with volcanic activity, J. Volcanol. Geotherm. Res., 81, 297-310, https://doi.org/10.1016/S03770273(98)00012-2

Giammanco, S., M. Ottaviani, M. Valenza, E. Veschetti, E. Principio, G. Giammanco and S. Pignato (1998b). Major and trace elements geochemistry in the ground waters of a volcanic area Mount Etna (Sicily, Italy), Water Res., 32, 19-30, https://doi.org/10.1016/S0043-1354(97)00198-X.

Giammanco, S., F. Parello, B. Gambardella, R. Schifano, S. Pizzullo and G. Galante (2007). Focused and diffuse effluxes $\mathrm{Of} \mathrm{CO}_{2}$ from mud volcanoes and mofettes south of Mt. Etna (Italy), J. Volcanol. Geotherm. Res., 165, 1-2, 4663, https://doi.org/10.1016/j.jvolgeores.2007.04.010.

Giggenbach, W.F. (1988). Geothermal solute equilibria. Derivation of Na-K-Mg-Ca geoindicators, Geochimica et Cosmochimica Acta, 52 12, 2749-2765, https://doi.org/10.1016/0016-7037(88)90143-3.

Giggenbach, W.F. and R.S. Corrales (1992). Isotopic and chemical composition of waters and steam discharges from volcanic-magmatic-hydrothermal systems of the Guanacaste Geothermal Province, Costa Rica, Appl. Geochem., 7 4, 309-332. https://doi.org/10.1016/0883-2927(92)90022-U.

Giggenbach, W.F., D.S. Sheppard, B.W. Robinson, M.K. Stewart and G.L. Lyon (1994). Geochemical structure and position of the Waiotapu geothermal field, New Zealand, Geothermics, 23, 599-644, https://doi.org/10.1016/0375-6505(94)90022-1

Gonfiantini, R. (1986). Environmental isotopes in lake studies, In: Fritz P., Fontes J.Ch. (Eds), Handbook of Environmental Isotopes Geochemistry, 2, Elsevier, Amsterdam, 133-168.

Grassa, F. (2002). Geochemical processes governing the chemistry of groundwater hosted within the Hyblean aquifers (Southeastern Sicily, Italy), Ph.D. Thesis, Univ. of Palermo.

Grassa, F., G. Capasso, R. Favara and S. Inguaggiato (2006). Chemical and isotopic composition of waters and dissolved gases in some thermal springs of Sicily and adjacent volcanic islands, Italy, Pure Appl. Geophys., 163, 4, 781-807, https://doi.org/10.1007/s00024-006-0043-0.

Grasso, M. and F. Lentini (1982). Sedimentary and Tectonic Evolution of the Eastern Hyblean Plateau (Southeastern Sicily) during Late Cretaceous to Quaternary Time, Palaeogeog. Palaeoclim. Palaeoecol., 39, 3-4, 261-280, https://doi.org/10.1016/0031-0182(82)90025-6.

Grasso, M., H.M. Pedley, R. Maniscalco and R. Ruggieri (2000). Geological context and explanatory notes of the "Carta Geologica del settore centro-meridionale dell’Altopiano Ibleo", Mem. Soc. Geol. It., 55, 45-52.

Grasso, M., H.M. Pedley, B. Behncke, R. Maniscalco and G. Sturiale (2004). Integrated stratigraphic approach to the study of the Neogene-Quaternary sedimentation and volcanism in the northern Hyblean Plateau (Sicily), in: Mapping Geology in Italy, G. Pasquare and C. Venturini (editors), APAT, Rome, 159-166.

Grasso, M. and C.D. Reuther (1988). The western margin of the Hyblean Plateau: a neotectonic transform system on the SE Sicilian foreland, Ann. Tectonicae, II, 2, 107-120.

Hem J.D. (1985). Study and interpretation of the chemical characteristics of natural water, USGS Water-supply paper, 2254, 263.

Henriquet, M., S. Dominguez, G. Barreca, J. Malavieille, C. Cadio and C. Monaco (2019). Deep Origin of the Dome-Shaped Hyblean Plateau, Southeastern Sicily: A New Tectono-Magmatic Model, Tectonics, 38, 12, 44884515, https://doi.org/10.1029/2019TC005548.

Inguaggiato, S., G. Pecoraino and F. D’Amore (2000). Chemical and isotopical characterisation of fluid manifestations of Ischia Island (Italy), J. Volcanol. Geotherm. Res., 99, 151-178, doi: 10.1016/S0377-0273(00)00158-X.

Kendall, C. and T.B. Coplen (1985). Multisample conversion of water to hydrogen by zinc for stable isotope determination, Anal. Chem., 57, 1437-1440. https://doi.org/10.1021/ac00284a058.

Langelier, W.E. and H.F. Ludwig (1942). Graphical method for indicating the mineral character of natural water, Am. Water Works Ass. J., 34, 3, 335-352. https://doi.org///www.jstor.org/stable/41232803.

Lanzafame, G., M. Neri, M. Coltelli, L. Lodato and D. Rust (1997). North-south compression in the Mt. Etna region (Sicily): spatial and temporal distribution, Acta Vulcanol., 9, 1-2, 121-133.

Lentini, F., M. Grasso and S. Carbone (1987). Introduzione alla geologia della Sicilia e guida all'escursione, Convegno Soc. Geol. It., Naxos/Pergusa, Aprile 1987.

Lentini, F., S. Carbone, S. Catalano and M. Grasso (1996). Elementi per la ricostruzione del quadro strutturale della Sicilia Orientale, Mem. Soc. Geol. It., 51, 179-195. 


\section{Gloria Maria Ristuccia et al.}

Leontiadis, I.L., S. Vergis and Th. Christodoulou (1996). Isotope hydrology study of areas in Eastern Macedonia and Thrace, northern Greece, J. Hydrology, 182, 1-17, https://doi.org/10.1016/0022-1694(95)02945-1.

Lickorish, W. H., M. Grasso, R.W.H. Butler, A. Argnani and R. Maniscalco (1999). Structural styles and regional tectonic setting of the "Gela Nappe" and frontal part of the Maghrebian thrust belt in Sicily, Tectonics, 18, 4, 655-668. https://doi.org/10.1029/1999TC900013.

Lo Giudice, E., G. Patane`, R. Rasa`and R. Romano (1982). The structural framework of Mt. Etna, Mem. Soc. Geol. Ital., 23, 125-58.

Lo Russo, S., C. Boffa and M.V. Civita (2009). Low-enthalpy geothermal energy: An opportunity to meet increasing energy needs and reduce $\mathrm{CO}_{2}$ and atmospheric pollutant emissions in Piemonte, Italy, Geothermics, 38, 2, 254-262, https://doi.org/10.1016/j.geothermics.2008.07.005.

Marini, L. (2000). Geochemical techniques for the exploration and exploitation of geothermal energy, Laboratorio di Geochimica, Dip.Te.Ris., University of Genoa, Italy, 106, https://geothermalcommunities.eu/assets/elearning/2.3.chile.pdf

Mattia, M., V. Bruno, F. Cannavò and M. Palano (2012). Evidences of a contractional pattern along the northern rim of the Hyblean Plateau (Sicily, Italy) from GPS data, Geologica Acta, 10, 12, 63-70, https://doi.org/1010.1344/105.000001705

Minissale, A., Donato, A., Procesi, M., Pizzino, L., Giammanco, S. (2019). Systematic review of geochemical data from thermal springs, gas vents and fumaroles of Southern Italy for geothermal favourability mapping, EarthSci. Rev., 188, 514-535, https://doi.org/10.1016/j.earscirev.2018.09.008.

Monaco, C. and L. Tortorici (2000). Active faulting in the Calabrian arc and eastern Sicily, J. Geodyn., 29, 3-5, 407424. https://doi.org/10.1016/S0264-3707(99)00052-6.

Monaco, C., M. Bianca, S. Catalano, G. De Guidi and L. Tortorici (2002). Sudden change in the late Quaternary tectonic regime in eastern Sicily: evidences from geological and geomorphological features, Boll. Soc. Geol. It., 1, 901-913.

Mook, W.G., J.C. Bemmerson, and W.H. Steverman (1974). Carbon isotope fractionation between dissolved bicarbonate and gaseous carbon dioxide, Earth Planet. Sci. Lett., 22, 169-176, https://doi.org/10.1016/0012$821 \mathrm{X}(74) 90078-8$.

Mutlu, H. and N. Güleç (1998). Hydrogeochemical outline of thermal waters and geothermometry applications in Anatolia (Turkey), J. Volcanol. Geotherm. Res., 85, 495-515, https://doi.org/10.1016/S0377-0273(98)00068-7.

Neri, M., E. Rivalta, F. Maccaferri, V. Acocella and R. Cirrincione (2018). Etnean and Hyblean volcanism shifted away from the Malta Escarpment by crustal stresses, Earth Planet. Sci. Lett., 486, 15-22. https://doi.org/10.1016/j.epsl.2018.01.006.

Nicholson, K. (1993). Geothermal Fluids. Chemistry and Exploration Techniques, Springer.

Ogniben, L. (1969). Schema introduttivo alla geologia del confine calabro-lucano, Mem. Soc. Geol. It., 8, 453-763.

Patacca, E., R. Sartori and P. Scandone (1990). Thyrrenian basin and Apenninic arcs: kinematic relations since Late Tortonian times, Mem. Soc. Geol. It., 45, 425-451.

Parkhrust, D.L. (1995). User's guide to PHREEQC - A computer program for speciation, reaction path, advective transport, and inverse geochemical calculation, U.S. Geological Survey Water Resource Investigations, 95-4227.

Pecoraino, G. and S. Giammanco (2005). Geochemical Characterization and Temporal Changes in Parietal Gas Emissions at Mt. Etna (Italy) During the Period July 2000 - July 2003, Terr. Atmosph. Ocean. Sci., 16(4), 805841, https://doi.org/10.3319/TAO.2005.16.4.805(GIG).

Pedley, H. M., M. Grasso, R. Maniscaldo, B. Behncke, A. Di Stefano, S. Giuffrida and G. Sturiale (2001). The sedimentology and palaeoenvironment of Quaternary temperate carbonates and their distribution around the northern Hyblean Mountains (SE Sicily), Boll. Soc. Geol. Ital., 121, 233-255.

Reed, M. and N. Spycher (1984). Calculation of $\mathrm{pH}$ and mineral equilibria in hydrothermal waters with application to geothermometry and studies of boiling and dilution, Geochimica Cosmochimica Acta, 78, 7, 1479-92.

Reuther, C. D., Z. Ben-Avraham and M. Grasso (1993). Origin and role of major strike-slip transfers during plate collision in the central Mediterranean, Terra Nova, 5, 3, 249-257, https://doi.org/10.1111/j.13653121.1993.tb00256.x.

Ristuccia, G. M., A. Di Stefano, A.M. Gueli, C. Monaco, G. Stella and S.O. Troja (2013). OSL chronology of Quaternary terraced deposits outcropping between Mt. Etna volcano and the Catania Plain (Sicily, southern Italy), Phys. Chem. Earth, 63, 36-46, https://doi.org/10.1016/j.pce.2013.03.002.

Ristuccia, G.M., P. Bonfanti, S. Giammanco and G. Stella (2019). Assessment of the geochemical potential in a 
complex tectonic environment of south-east Sicily: new insights from hydrochemical data, Front. Earth Sci, 7, 18, 1-13, https://doi.org/10.3389/feart.2019.00088.

Schiano, P., R. Clocchiatti, L. Ottolini and T. Busa` (2001). Transition of Mount Etna lavas from a mantle-plume to an island-arc magmatic source, Nature, 412, 900-904.

Schmincke, H.-U., B. Behncke, M. Grasso and S. Raffi (1997). Evolution of the northwestern Iblean Mountains, Sicily: Uplift, Pliocene/Pleistocene sea-level changes, paleoenvironment, and volcanism, Geol. Rundsch., 86, 637669, https://doi.org/10.1007/s005310050169.

Sheppard, S.M.F. (1986). Characterization and isotopic variations in natural waters. In: Valley, J.W., Taylor Jr., H.P., O’Neil, J.R. (Eds.), Stable isotopic in high temperatures geological process, Rev. Mineral., 16, 165-183.

Sortino, F., S. Inguaggiato and S. Francofonte (1991). Determination of HF, $\mathrm{HCl}$, and total sulphur in fumarolic fluids by ion chromatography, Acta Vulcanol., 1, 89-91.

Swan, A. R. H. and M. Sandilands (1995). Introduction to geological data analysis, Blackwell Science, Oxford.

Truesdell, A.H. (1975). Geochemical techniques in exploration, Proc. 2nd UN Symp., Development and Use of Geothermal Resources, 1, 53-86.

Trumpy, E., A. Donato, G. Gianelli, G. Gola, A. Minissale, D. Montanari, A. Santilano and A. Manzella (2015). Data integration and favourability maps for exploring geothermalsystems in Sicily, southern Italy, Geothermics, 56, 1-16, http://dx.doi.org/10.1016/j.geothermics.2015.03.004.

Yellin-Dror, A., M. Grasso, Z. Ben-Avraham and G. Tibor (1997). The subsidence history of the northern Hyblean plateau margin, southeastern Sicily, Tectonophysics, 282, 277-289, https://doi.org/10.1016/S0040-1951 (97)00228-X.

Zimmerman, U., D. Ehhalt and K.O. Munnich (1967). Soil water movement and evapo-transpitation: change in the isotopic composition of the water. In: Isotopes in Hydrology, IAEA, Vienna, 567-585.

*CORRESPONDING AUTHOR: Gloria Maria RISTUCCIA,

Istituto Nazionale di Geofisica e Vulcanologia, Catania, Italy

e-mail: gloria.ristuccia@hotmail.com

(c) 2021 the Author(s). All rights reserved.

Open Access. This article is licensed under a Creative Commons Attribution 3.0 International 